\title{
Spatial and temporal patterns of benthic macrofaunal communities on the deep continental margin in the Gulf of Guinea
}

\author{
J. Galéron ${ }^{\mathrm{a},{ }^{*}}$, L. Menot ${ }^{\mathrm{b}}$, N. Renaud ${ }^{\mathrm{a}}$, P. Crassous $^{\mathrm{a}}$, A. Khripounoff ${ }^{\mathrm{a}}$, C. Treignier $^{\mathrm{c}}$ and M. \\ Sibuet $^{b}$
}

\author{
a Ifremer, Département DEEP/LEP, Centre de Brest, BP70, 29280 Plouzané, France \\ ${ }^{\mathrm{b}}$ Institut Océanographique, 195 Rue Saint Jacques, 75005 Paris, France \\ c Laboratoire d'Océanographie et du Climat: Expérimentation et Approches Numériques, IPSL/UPMC/UMR \\ CNRS 7159, Case 100, 4 place Jussieu, 75252 Paris Cedex 05, France
}

*: Corresponding author : J. Galéron, email address : Joelle.Galeron@ifremer.fr

\begin{abstract}
:
Density, taxonomic composition at higher taxon level and vertical distribution of benthic macrofaunal communities and sediment characteristics (pore water, nitrogen, organic carbon, sulfur, $\mathrm{C} / \mathrm{N}$ ratio, nalcohol biomarkers) were examined at three deep sites on the Congo-Gabon continental margin. This study was part of the multidisciplinary BIOZAIRE project that aimed at studying the deep benthic ecosystems in the Gulf of Guinea. Sampling of macrofaunal communities and of sediment was conducted during three cruises (January 2001, December 2001 and December 2003) at two downslope sites (4000 $\mathrm{m}$ depth), one located near the Congo submarine channel (15 km in the south) and the other one far from the channel (150 km in the South). The third area located $8 \mathrm{~km}$ north of the Congo channel in the surroundings of a giant pockmark at $3160 \mathrm{~m}$ depth was sampled during one cruise in December 2003.
\end{abstract}

At these three locations the macrofaunal communities presented relatively high densities (327-987 ind. $0.25 \mathrm{~m}-2$ ) compared with macrofaunal communities at similar depths; that is due to high levels of food input related to the Congo river and submarine system activities that affect the whole study area. The communities were different from each other in terms of taxonomic composition at higher taxon level (phylum, class, order for all the groups except for the polychaetes classified into families). The polychaetes dominated the communities and were responsible for the increase in densities observed at both deep sites $(4000 \mathrm{~m}$ ) between January 2001 and December 2003 whereas the tanaidaceans, the isopods and the bivalves were the other most abundant taxa responsible for the spatial differences between these sites. The community at $3150 \mathrm{~m}$ differed from the two deep communities by higher abundances in bivalves, nemerteans and holothuroids. The composition of the polychaete community also differed among sites.

In the vicinity of the Congo channel, the expected positive effect of the additional organic matter transported through the turbiditic currents on to the surrounding benthic communities was not observed, as the increase in densities during the study period was higher at the site located away from the Congo channel than near the channel ( $80 \%$ vs $30 \%)$. That may be due to the low food value of the organic matter of terrestrial origin carried through the turbidites, and/or to the disturbance caused by these turbidites. Conversely, far from the channel the macrofaunal communities benefit from organic matter of higher energetic value originating mainly from marine sources, but also from continental sources, carried by the Congo plume or by near-bed currents across or along the continental slope. Spatial and temporal variability in trophic and physical characteristics of the sediment habitat at both deep sites also affected the vertical distribution of the macrofaunal communities. 
The activities of the very active Congo system structure the deep macrofaunal communities on a large area in terms of densities, composition and vertical distribution. The food input is enhanced at regional scale as well as the heterogeneity of the sediment characteristics, mainly in terms of organic matter quality (marine vs terrigenous). In turn, the densities are enhanced as well as the regional diversity of the macrofaunal communities in terms of taxonomic composition and distribution.

Keywords: Atlantic; Equatorial west Africa margin; Congo-Angola margin; Congo canyon; Macrofauna; Community structure; Distribution; Deep sea

\section{Introduction}

The general objectives of the multidisciplinary BIOZAIRE project, developed by Ifremer in partnership with the French oil company Total, were to discover, describe and understand the then unknown benthic ecosystems in the deep Gulf of Guinea. (Sibuet et al., 2002).

The main feature of the Gulf of Guinea (west equatorial Africa) is the presence of one of the world's largest active submarine systems, the Congo system. The canyon is directly connected to the mouth of the Congo river that is the second world river in terms of water discharges to the ocean, and that is responsible for a mean organic carbon export to the Atlantic ocean of about $7 \%$ of the total world river exportations, with limited interannual variability (Coynel et al., 2005). The Congo submarine canyon deeply and sinuously incises the Congo-Angola continental shelf and 
slope (Babonneau et al., 2002; Savoye et al., 2000), westward down to the abyssal plain where it ends, forming a large deep sea fan $760 \mathrm{~km}$ from the river mouth at a water depth of $4800 \mathrm{~m}$.

Canyons are regular features along most ocean margins and they appear to be important as sites of enhanced productivity and as conduits of continental detritus to the deep sea (Vetter and Dayton, 1998). The role of canyons in providing high quantities of organic material to the benthic communities has been investigated in many areas from shelves and slopes to the deep sea (Aller and Stupakoff, 1996; Duineveld et al., 2001; Gage et al., 1995; Houston and Haedrich, 1984; Lamont et al., 1995; Maurer et al., 1994; Rowe et al., 1982; Soetaert et al., 1991; Vetter and Dayton, 1998) mainly by comparing communities in canyons and in the surroundings. These authors found dense and diverse communities in canyons compared with the adjacent areas.

The Congo system is expected to influence the surrounding deep benthic ecosystems by providing trophic inputs originating from the continent and carried in the upper layer of water by its plume and in the benthic boundary layer by the episodic turbiditic currents that overflow the flanks of the channel (Khripounoff et al., 2003). The Congo plume is permanent with probably weak interannual and seasonal variations as observed for the Congo River discharge (Coynel et al., 2005); it has a large extension affecting the whole study area (Treignier et al., 2006; van Bennekom and Berger, 1984). Nutrient concentrations in the river plume are high due to direct river influence and to river-induced upwelling (van Bennekom et al., 1978). However, primary production in the river plume is reduced because of the large quantities of suspended matter clouding the waters. The turbiditic currents in the Congo submarine system are episodic. They directly affect the benthic habitat at least on a few kilometres on both sides of the Congo channel by bringing onto the seafloor high quantities of particulate matter of continental origin that have a low food value (Khripounoff et al., 2003; Treignier et al., 2006).

Moreover, Picaut (1983) and Voituriez and Herbland (1982) demonstrated that a highly seasonal coastal upwelling affects the study area and that it extends far offshore, enhancing the primary productivity in the photic layer in the whole area. In many deep ocean areas, seasonal or episodic pulses of fresh food to the deep sea have been shown to result in increasing benthic population numbers (Billett et al., 2001; Drazen et al., 1998; Galéron et al., 2001; Vanreusel et al., 2001), increasing total community metabolism and megafaunal activity (Bett et al., 2001), in variations in 
vertical distribution of infaunal communities (Galéron et al., 2001; Jumars et al., 1990; Witte, 2000), and in changes in the benthic community structure (Billett et al., 2001; Vanreusel et al., 2001).

In deep ocean basins the organic matter fuelling the benthic communities has a predominantly marine origin as is provided mainly by the primary production in the photic water layer whereas continental margins receive organic matter of both marine and terrestrial origin. The origin (marine vs terrigenous) of the sedimentary organic matter is thought to have a pronounced influence on the benthic fauna (Dauwe et al., 1998).

In the present study, the influence of the Congo submarine system on the benthic communities is evaluated by assessing the spatial and temporal patterns of the macrofaunal community structure and vertical distribution in relation to the sediment composition at two downslope sites at $4000 \mathrm{~m}$ depth and at a third site at 3150m depth, located in the vicinity of the Congo channel and of a very active pockmark system.

\section{Material and Methods}

\section{Study areas}

Three areas were chosen in the Gulf of Guinea to study the deep benthic ecosystems (Figure 1). The site ZD, located on the levee, 15km south of the Congo channel, was shown under regime of strong erratic continental inputs during short periods of time, alternating with longer periods of lower particle input of pelagic and continental origins (Khripounoff et al., 2003; Treignier et al., 2006). The site ZC, located 150km in the south was supposed to be out of influence of the Congo channel activities. Both sites are located downslope of the Congo-Angola margin at 4000m water depth. The third area is located between 6 and $9 \mathrm{~km}$ north of the Congo channel at 3150m depth in the surroundings of the giant pockmark REGAB described by Ondréas et al. (2005) and Olu-Le Roy et al. (2007). Six sites are located along two transects North and South of the active pockmarck area, 250m (R6 and R7), 500m (R4 and R9), and 1000m (R3 and R10) from the carbonate concretion edges, and one site (R) is located 250m from the active area in the SW (Figure 2).

\section{Data collection and sample processing}

\section{Macrofauna}


Macrofauna sampling was carried out during three BIOZAIRE cruises on the RV l'Atalante: BIOZAIRE 1 (2-15 Jan 2001) (also named BZ1), BIOZAIRE 2 (15 Nov-4 Dec 2001) (BZ2) and BIOZAIRE 3 (12 Dec 2003-10 Jan 2004) (BZ3). Macrofauna sensu stricto (i.e. excluding Nematoda, Copepoda Harpacticoida and other meiofaunal taxa) were collected using an USNEL box corer (0.25 $\mathrm{m}^{2}$ sample area) (Hessler and Jumars, 1974). Cores retaining the overlying water and with visually non disturbed surface were selected for analysis. The numbers of replicate samples per site and per cruise are presented in table 1 . Samples were processed immediately after recovery. The overlying water was siphoned, and the upper $15 \mathrm{~cm}$ of sediment was sliced into five depth strata $(0-1 \mathrm{~cm}, 1-3 \mathrm{~cm}, 3-5 \mathrm{~cm}, 5-10 \mathrm{~cm}, 10-15 \mathrm{~cm})$. The upper two layers were immediately placed into $4 \%$ borax-buffered formaldehyde prior to sieving in order to minimize the deterioration of organisms. Sieving was carried out through a stack of $1 \mathrm{~mm}, 500 \mu \mathrm{m}, 300 \mu \mathrm{m}, 250 \mu \mathrm{m}$ mesh sieves. The subsamples were fixed in $4 \%$ formaldehyde. In the laboratory, samples were stained with Rose Bengal. The organisms were extracted by successive elutriation until complete removal and they were sorted out under a dissecting microscope. Specimens classified by Phylum, Order or Class (or Family for polychaetes) were stored in $70 \%$ ethanol. Polychaete families collected at sites ZC and ZD were assigned to feeding guilds following Fauchald and Jumars (1979).

\section{Sediment chemical characteristics}

Sediment cores ( $\sim 25 \mathrm{~cm}$ long) were collected at sites ZC and ZD during the three BIOZAIRE cruises and at the six transect sites (R3, R4, R6, R7, R9, R10) during BZ3. They were recovered using a multiple corer, equipped with 6.2cm diameter tubes.

Analyses of pore water content, nitrogen, organic carbon, and sulfur were performed according to the protocol described in Rabouille et al. (this volume). Mean values of these parameters and of $\mathrm{C} / \mathrm{N}$ ratios were calculated on the first $3 \mathrm{~cm}$ of sediment.

Molecular analysis of $n$-alcohol biomarkers was carried out on surficial sediments $(0-0.5 \mathrm{~cm})$ collected at sites ZC and ZD during the three BIOZAIRE cruises. The detailed collection and analytical methodology is described in Treignier et al. (2006). The $n$-alcohol distribution reflects the contributions of planktonic organisms and higher plant inputs to the sediment; the freshwater and marine plankton contribution is revealed by the $\mathrm{C}_{14}$ to $\mathrm{C}_{20} n$-alcohols $\left(<\mathrm{C}_{20}\right)$, whereas the $\mathrm{C}_{22}$ to $\mathrm{C}_{35}$ n-alcohols $\left(>\mathrm{C}_{22}\right)$ indicate the higher plant inputs (Treignier et al., 2006).

\section{Statistical analyses}


A two-way analysis of variance was used to compare faunal densities at the sites ZC and ZD, between the cruises BZ1 and BZ3. The ANOVA model was of the form: $\mathrm{y}=\mu+$ Site + Cruise + Site $\mathrm{x}$ Cruise, where $\mu$ is a constant. The densities were Log-transformed to homogenize variances. The two samples from the cruise BZ2 were not used in the analysis in order to keep a balanced design. Macrofaunal densities at sites R3, R4, R6, R7, R9, R10 were also compared (ANOVA).

Variations in community composition between sites were analysed using a Between-Group Principal Component Analysis (bgPCA) (Dodélec and Chessel, 1987). Centred PCA were performed on sample x taxa matrices. As described in Legendre and Gallagher (2001), density data were transformed in order to use the Hellinger distance among samples rather than the Euclidean distance, normally preserved in PCA. In the analysis of macrobenthic communities, the Hellinger distance offers several advantages over the Euclidean distance, in particular it gives a lower weight to dominant taxa and does not consider double absence as an indicator of similarity between samples (Legendre and Gallagher, 2001). Following the PCA, the samples were clustered into their respective sites for each sampling year and Between Group analyses were run on the results of the PCA. This bgPCA allows focusing on between sites variability and testing for the significance of differences between sites using Monte-Carlo permutations (Dodélec and Chessel, 1987).

A Principal Component Analysis was also performed on data for pore water, particulate nitrogen, particulate sulphur, organic carbon and C/N ratio. Data were Log-transformed and standardized in order to homogenize variances and evenly weight the variables. Multivariate analyses and tests were performed with the software AD4 (Thioulouse et al., 1997).

\section{Results}

\section{Community structure}

Macrofaunal structure is presented in table 2 and in figure 3. At ZC the macrofaunal community was composed of 13 to 16 higher taxa depending on the sampling cruise, 13 to 17 at ZD, and varied from 17 to 20 among transect sites. Polychaeta was the dominant higher taxon of the macrofaunal community at all sites, contributing between $40 \%$ and $76 \%$ to the total density. At all sites the other dominant components were regularly the tanaidaceans, the isopods and the bivalves. At sites located around the pockmark area (R, R3, R4, R6, R7, R9,R10), we also found 
nemerteans regularly present with densities contributing from 3 to $6 \%$ to the macrofaunal density, and sipunculids accounted for $5 \%$ of the community at R7. Four dominant polychaete families were present at all sites and during each cruise: the cirratulids, dominant at ZC, the paraonids, dominant at ZD, the spionids, dominant at R and the ophelids. Some families accounting for more than $3 \%$ of the polychaetes were present at a single site (hesionids and ampharetids at ZC), or at two sites (nereidids and syllids at ZC and ZD, lumbrinerids at ZC and "R” sites, pilargids at ZD and "R" sites).

\section{Macrofaunal densities}

Total densities varied from 327 to 987 ind. $0.25 \mathrm{~m}^{-2}$ among the three sites (Table 2). Significant differences in densities were found between sites ZC and ZD for total macrofauna ( $\mathrm{p}<0.05$ ), tanaidaceans ( $\mathrm{p}<0.01)$, isopods $(\mathrm{p}<0.05)$ and bivalves $(\mathrm{p}<0.05)$ while the polychaetes showed no significant difference between sites (Table 3). Variations in total mean densities and in polychaete densities between January 2001 and December 2003 were significant at both sites $(\mathrm{p}<0.01)$. The cruise:site test shows that changes in total densities and in densities of tanaidaceans are significantly different at sites ZC and ZD $(\mathrm{p}<0.1)$. Considering the polychaetes grouped in trophic groups, densities of surface deposit feeders increased progressively from January 2001 to December 2003 at both sites, while sub-surface deposit feeder and mobile carnivorous densities were stable from January to December 2001 and then increased from December 2001 to December 2003 (Figure 4). Significant differences were highlighted for each polychaete trophic group between January 2001 and December 2003 at sites ZC and ZD (Table 3).

No significant difference was found between total mean densities at the six transect sites north and south of the REGAB area.

\section{Vertical distribution}

Temporal evolution of vertical distribution of the macrofaunal communities at sites ZC and ZD is presented in figure 5. At ZC during BZ1 and BZ2, more than $80 \%$ of the organisms were more or less equally shared among the two top layers of sediment $(0-1$ and $1-3 \mathrm{~cm})$ while during BZ3 the main part of the community (64\%) was present in the surface layer and then the numbers of organisms decreased from the surface to the deeper layers. At ZD during BZ1 and BZ2 we had more than 85\% of the community distributed among the three top layers of sediment, with higher numbers of organisms in the subsurface layer $(1-3 \mathrm{~cm})$ than in the surface layer. During BZ3 we noticed higher numbers in the two top 
sediment layers. When observing together the vertical profiles at ZC and ZD we noticed a trend of the macrofaunal community to live deeper in the sediment column at ZD than at ZC.

At the six transect sites (Figure 6) sampled during BZ3 (R3, R4, R6, R7, R9, R10), the macrofauna exhibited similar trends of distribution than at $\mathrm{C}$ and $\mathrm{D}$ during the same cruise, with decreasing abundances from the surface to the deep layers.

\section{PCA analyses of macrofaunal data}

Results of the PCA performed on higher taxon (phylum, class or order depending on the taxon) density data collected at sites ZC and ZD during the three cruises, at R during BZ2 and at the six transect sites (R3, R4, R6, R7, R9, R10) during BZ3 are presented in figure 7. The two first axes explained $71 \%$ of the variability between the macrofaunal communities. Axis 1 highlighted the difference between the two deep sites (ZC, ZD) and the sites around REGAB (R, R3, R4, R6, R7, R9, R10). The assemblages at ZC and ZD during the three cruises were distant from each other. Taxa responsible for the difference between the deep sites and the " $\mathrm{R}$ " sites were mainly the tanaidaceans more abundant at the two deep sites, and the bivalves, nemerteans and holothuroids, more abundant at the " $\mathrm{R}$ ” sites. Polychaetes contributed also largely to separate the different assemblages.

The PCA performed on polychaete family densities at the same sites (Figure 8) indicated that the two first axes explained 64\% of the variability between assemblages. Axis 1 separated the "R" sites from the deep sites (ZC, ZD) and axis 2 separated ZC and ZD. The polychaete families that distinguish the " $R$ " sites from the deep sites were mainly the spionids, largely more abundant at " $R$ " sites, and for a lesser part the lumbrinerids and the pilargids abundant at " $\mathrm{R}$ ” sites, and the nereidids and the syllids abundant at ZC and ZD and nearly absent at " $\mathrm{R}$ ” sites. The site ZC was distinguished from ZD by the polychaete families hesionids, ampharetids and cirratulids, that were more abundant at ZC, while the paraonids and the pilargids were more abundant at ZD. The sigalionids were responsible for the separation of the assemblages during the three cruises at ZC and ZD. We also noted the grouping of the " $\mathrm{R}$ ” sites in contrast to a larger distance between the three $\mathrm{C}$ and $\mathrm{D}$ points.

When considering the polychaete families at ZC and ZD (Figure 9), axes 1 and 2 represented 75\% of the variability between assemblages. This analysis confirmed the role of the different families in separating the ZC and ZD communities (paraonids and pilargids at D, hesionids, syllids at 
ZC), and highlighted the contribution of the families responsible for the separation of the cruises (sigalionids, ampharetids, pholoids, dorvilleids and syllids).

\section{Chemical characteristics of the sediment}

Organic carbon concentrations in the sediment at ZC and ZD sites during BZ1, BZ2 and BZ3 (Figures 10a and 10b) showed unusual profiles in this deep sea context with higher values around $10 \mathrm{~cm}$ depth than in the surface layer. The difference observed between the two sites was a higher concentration in the surface layer at ZD during BZ2.

The mean values of water content, organic carbon, sulfur, nitrogen and $\mathrm{C} / \mathrm{N}$ ratio for the top $3 \mathrm{~cm}$ of sediment at ZC, ZD and transect "R" sites during BZ3 are presented in figure 11. The site R7 seemed different from the other sites as it was characterized by the lowest pore water content and the highest N, C and S concentrations. Pore water content varied from 79 to 84\% among sites. Globally the transect sites presented higher concentrations in organic matter (C, N) and in sulfur than the deep sites. Sediments at ZC and ZD sites differed by their pore water content and by their concentration in nitrogen, both higher at ZC than at ZD. The $\mathrm{C} / \mathrm{N}$ ratio clearly separated the two deep sites with the highest value for ZD and the lowest for ZC while the transect sites presented intermediate values.

PCA performed on the set of data from all sites and all cruises (Figure 12) indicated that axes 1 and 2 explain 84\% of the variability between sites. Axis 1 separated the transect sites from the deep sites ZC and ZD, axis 2 separated ZC from ZD. We also noticed that R7 was distant from the other transect sites.

\section{Biomarker composition and concentrations in the sediment}

The $n$-alcohol distribution exhibited 2 modes with maxima at $\mathrm{C}_{16}$ (or $\mathrm{C}_{18}$ ) and $\mathrm{C}_{28}$ (or $\mathrm{C}_{30}$ ) (Table 4). The 2 modes $\left(\mathrm{C}_{14}\right.$ to $\mathrm{C}_{20}$ and $\mathrm{C}_{22}$ to $\mathrm{C}_{35}$ ) displayed a strong predominance of even-over-odd chain length $n$-alcohols.

At site ZC, the inputs of terrigenous and marine material to the surficial sediments varied quantitatively and qualitatively along the time, as shown in figure 13a by the $n$-alcohol concentrations ( $\mu \mathrm{g} / \mathrm{g}$ of dry sediment) and the ratio of the short/long chain $n$-alcohols. The concentrations were, by far, higher during BZ1 than during BZ2 and BZ3. During BZ1, the $<\mathrm{C}_{20}$ and $>\mathrm{C}_{22}$ concentrations reached 53.9 and $11.7 \mu \mathrm{g} / \mathrm{g}$, 
respectively. Those concentrations were 7 and 12 times higher than the average reported for BZ2 and BZ3. Marine n-alcohols remained predominant during BZ1 and BZ2 as demonstrated by the ratio $\left(\Sigma \mathrm{C}_{14}-\mathrm{C}_{20}\right) /\left(\Sigma \mathrm{C}_{22}-\mathrm{C}_{35}\right)$.

At site $\mathrm{ZD}$, the terrigenous and marine inputs to surficial sediments also varied. Marine $<\mathrm{C}_{20} n$-alcohol concentrations varied from 5.5 to

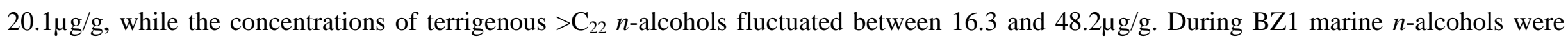
almost equalled by the terrigenous $n$-alcohol (20.1 vs $16.3 \mu \mathrm{g} / \mathrm{g}$, respectively) in the surface sediments, as shown by the ratio $\left(\Sigma \mathrm{C}_{14}-\mathrm{C}_{20}\right) /\left(\Sigma \mathrm{C}_{22}-\right.$

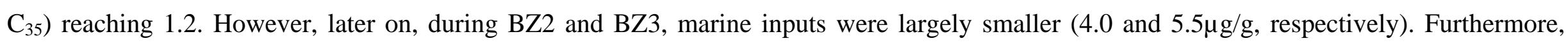
those marine $n$-alcohols accounted for minor $\left(\left(\Sigma \mathrm{C}_{14}-\mathrm{C}_{20}\right) /\left(\Sigma \mathrm{C}_{22}-\mathrm{C}_{35}\right)<0.3\right)$ in the total $n$-alcohols. Indeed, terrigenous $n$-alcohol inputs reached $48.3 \mu \mathrm{g} / \mathrm{g}$ during BZ2, and decreased down to $16.8 \mu \mathrm{g} / \mathrm{g}$ during BZ3.

\section{Discussion}

The sites investigated in the present study are located down slope of the Congo-Angola continental margin. They receive organic inputs from pelagic origin and also from terrestrial origin varying in space and time as shown by Treignier et al. (2006) and in the present study by $\mathrm{C} / \mathrm{N}$ ratios (Figure 11) and by biomarker concentrations in the surficial layer of sediment (Figures 13a, 13b). The terrestrial inputs are carried from the continent to the deep seabed through different ways. They may be carried by the Congo plume that extends on a large area (Picaut, 1983; van Bennekom and Berger, 1984; van Bennekom et al., 1978) or by high energy currents in the Congo submarine system that may result in turbidites overflowing the flanks of the channel and carrying large quantities of fine particles on to the seabed in the vicinity of the channel (Khripounoff et al., 2003; Vangriesheim et al., this volume). They may also be carried by nearbed currents as suggested by Brind'Amour et al. (this volume). The response of the deep macrofaunal communities to the Congo activities is analysed by examining the spatial and temporal patterns of the structure and distribution of the macrofaunal communities and of selected sediment characteristics.

\section{Spatial patterns of macrofaunal assemblages}

Macrofaunal densities at the three study sites were in the range of those observed at similar depths in other areas as reported in the global-scale analysis of benthic standing stocks by Rex et al. (2006). Nevertheless our values were among the highest densities recorded at similar depth, and 
that may be due to different causes. Indeed, all the macrofaunal studies are not based on data obtained using the same methodology, particularly the mesh size can vary from $250 \mu \mathrm{m}$ to $500 \mu \mathrm{m}$. The data presented in the present study were obtained with a $250 \mu \mathrm{m}$ sieve that retains large numbers of small size organisms, abundant at this depth. Moreover, as suggested by Van Gaever et al. (this volume) who also found high meiofaunal densities and by Rabouille et al. (this volume) who measured high values of oxygen consumption at the same locations, the high faunal densities recorded must also be related to the influence of the Congo plume (van Bennekom et al., 1978) and related upwelling activities (Picaut, 1983; Voituriez and Herbland, 1982) that enhance organic inputs on to the seabed, which, in turn favour the development of dense benthic communities as reported at similar depth on the tropical East Atlantic margin (Galéron et al., 2000) or deeper and further in the south in the Angola basin $\left(18^{\circ} \mathrm{S}\right)$ (Kröncke and Turkay, 2003).

Macrofaunal assemblages at both deep sites (4000m) near the Congo channel (ZD) and far from the channel (ZC), and at 3150m around the REGAB pockmark area (R, R3, R4, R6, R7, R9, R10 sites) highlighted differences as did the meiofaunal assemblages (Van Gaever et al., this volume).

At the two deep sites (ZC and ZD) macrofaunal communities differed in their density (Table 3), in their taxonomic composition (Figures 7, 8) and in their vertical distribution (Figure 5). Polychaete densities were not significantly different between ZC and ZD but tanaidacean, isopod and bivalve densities were significantly lower at ZD than at ZC (Table 3). Among the polychaetes, paraonids and pilargids were well represented at ZD and nearly absent at ZC, whereas cirratulids, ampharetids and hesionids were present in higher numbers at ZC.

Differences between communities at ZC and ZD were also observed in their vertical distribution with the community living more evenly and deeply in the sediment column near the Congo channel than further (Figure 5).

Faunal densities being mainly driven by food availability, our results would suggest higher food inputs far from the Congo channel than near the channel. Nevertheless, Khripounoff et al. (2003), Rabouille et al. (this volume) and Treignier et al. (2006) as well as our results (Figures 10, 13) show that near the Congo channel (site ZD) the seafloor receives high quantities of organic material of continental origin carried by turbidites, while these inputs do not reach the seafloor at site ZC. At site ZC organic inputs are mainly of pelagic origin while they are mainly of terrestrial origin at ZD; that is shown by C/N ratio largely higher at ZD than at ZC and by biomarker composition of sediments (Figures 10, 13). The 
organic material carried by turbidites is already highly degraded when it reaches the deep seafloor (Treignier et al., 2006), and that may explain that benthic fauna does not benefit from that additional food input.

The low quality of organic matter at site ZD may also drive the vertical distribution of the macrofaunal community, as previously observed by Dauwe et al. (1998) and Flach and Heip (1996) who found a deeply penetrating fauna in presence of large amounts of refractory organic matter. Another reason could be the particular regime of particle inputs, characterized by erratic massive arrivals during short periods (Khripounoff et al., 2003) that likely bury the fauna living at the surface and favour the trend of fauna for living deeper in the sediment to avoid disturbances linked to the turbiditic activities.

Around the pockmark area, no significant difference in terms of density, taxonomic structure and vertical distribution of macrofauna was found among the six sites located at increasing distance along two transects north and south of the active pockmark area (R3, R4, R6, R7, R9,R10) nor with the site R located in the southwest (Figure 2). Nevertheless a higher density and a lower diversity of the community was found at R7, presumably located $250 \mathrm{~m}$ from the active area based on data available from ROV investigations during previous cruises that allowed mapping the distribution of megafauna and of some environmental parameters on the REGAB pockmark area (Ondréas et a.l, 2005, Olu-Le Roy et al., 2007). This discrepancy was due to a single boxcore that contained a largely higher number of organisms, similar to numbers found in the active pockmark area (Galéron, personal observation). The presence of a piece of carbonate concretion in this core suggests past or still present confined seeping activity that could result in high organic concentrations in sediment (Figure 11) that may support higher numbers of macrofaunal organisms. These observations led to suggest that the active area could extend to the north, further than described by ROV observations. Nevertheless, in this area, the seeping influence must be very local, in small spots as shown by our results as well as by meiofauna results (Van Gaever et al., this volume). If we exclude this single sample, we can consider that the six transect sites (R3, R4, R6, R7, R9, R10) and the R site made up a group that could be considered as a single habitat with close characteristics (Figures $8,11,12$ ) in which the macrofaunal community differed from the two other deep communities (ZC and ZD sites).

Differences were found in terms of composition between the "R" sites and the ZD and ZC sites (Figures 7, 8). In the "R" sites we found lower numbers of peracarid crustaceans, especially tanaidaceans, and of some polychaete families (especially nereidids and syllids) and higher numbers 
of holothuroids, nemerteans, bivalves, spionids, lumbrinerids and opheliids. These particularities did not seem to be linked to the influence of the pockmark area as these features were not observed within the active area community (Galéron, personal observation). The sediment concentrations in organic carbon and in nitrogen at the "R" sites (when excluding R7) were slightly higher than at the two deep sites (Figure 11) and the $\mathrm{C} / \mathrm{N}$ ratio was intermediate between ZC and ZD. So the " $\mathrm{R}$ " sites seemed to receive higher quantities of organic matter than the ZC and ZD sites, particularly in organic carbon and in a lesser proportion in nitrogen. This may be due to their location at a lower depth and closer to the continent. Moreover they also likely receive relatively high quantities of particulate matter of terrestrial origin as suggested by the $\mathrm{C} / \mathrm{N}$ ratios in the surficial layer of sediment. The sediments contained intermediate quantities of organic material of terrestrial origin, compared with the ZC and ZD sites. This material could be transported through the Congo plume, but also by overflows of turbiditic currents given the proximity of the canyon.

Our results suggest that in the whole area, the macrofaunal communities benefit from high levels of food inputs, linked to the Congo river and submarine system activities. The expected positive influence of the additional food input via the turbiditic currents on the surrounding benthic communities (i.e. by enhancing the densities) was not observed near the Congo channel. This may be due either to the low food value of the terrestrial material transported along the canyon/channel, and/or to the physical disturbance linked to the erratic and massive arrivals of particles onto the seabed. The turbidites also affect the vertical distribution of the macrofaunal communities that live deeper in the sediment column near the channel. The nature of organic matter fuelling the communities (terrestrial vs pelagic) seems to be more important than the quantity in structuring the macrofaunal communities in this complex area but the disturbances yielded by the Congo activities also affect the communities nearby the channel.

\section{Temporal variation of macrofaunal communities}

The sampling of macrofauna and sediment carried out at the two deep sites (ZC and ZD) during three cruises along the BIOZAIRE programme allowed us to investigate the temporal evolution of the macrofaunal communities and of the environmental conditions during a three year period. At both deep sites (ZC and ZD) macrofaunal communities underwent changes within this period in densities and in taxonomic composition 
(Table 3, Figure 3) as well as in vertical distribution in the sediment column (Figure 5). Significant increases in densities between January 2001 and December 2003 were observed at both sites, higher at ZC, far from the channel than at ZD near the channel. This shift in densities was due to the polychaetes (Table 3), particularly of the dominant families (cirratulids, paraonids, spionids) but also of other families contributing for a lesser part to the total density (sigalionids, ampharetids, dorvilleids) (Figures 7,8). Syllid and pholoid densities decreased in the meantime. When the polychaetes were grouped according to their trophic behaviour (Figure 4), the surface deposit feeder group exhibited increasing densities all along the study period while the increase in density of subsurface deposit feeders and mobile carnivores/omnivores was delayed and occurred after the second cruise. So it seems that the different components of the communities respond differently to changes in their habitat; the polychaetes feeding in the surficial layer of sediment appearing to be the most sensitive to potential changes. Significant differences in densities between January 2001 and December 2003 were found for each trophic group (Table 3).

It has already been shown that macrofaunal communities at abyssal depths could respond to an increase in fresh food supply by an increase in densities that could be evidenced within a timelag of a few months (Drazen et al., 1998; Galéron et al., 2001). Khripounoff et al. (2003) and Treignier et al. (2006) demonstrated that the site ZD near the Congo channel is under influence of turbiditic events. Following the turbiditic event recorded in March 2001, the quantity of organic matter reaching the bottom at ZD was equivalent to the annual usual input within 10 days. Nevertheless, the turbidite overflow remained confined in a $<400 \mathrm{~m}$ thick layer above the bottom, and it was suggested that its extension to the south was limited. Indeed, the effects of the turbiditic event on the sediment were recorded in the organic carbon concentration of the surface layer of sediment at ZD in December 2001 (Figures 10a, 10b) as well as in $n$-alcohol concentrations (Figures 13a, 13b), while no such change was recorded at ZC. Given that the increase in macrofaunal densities was even higher far from the channel than nearby, while the turbidite likely did not extend as far, we can conclude that the variations observed in macrofaunal communities are not directly linked to the turbiditic events.

At both sites ZC and ZD, biomarker concentrations in the surficial layer of sediment reflected changes during the BIOZAIRE study period, both in marine $<\mathrm{C}_{20} n$-alcohols and in terrigenous $>\mathrm{C}_{22} n$-alcohols (Figures 13a, 13b). At ZC a shift in total $n$-alcohol concentrations was observed between BZ1 and the following cruises, with a clearly greater difference in marine than in terrigenous $n$-alcohols. That should be explained by largely higher inputs of organic material just before BZ1, particularly of material of pelagic origin. At ZD, total $n$-alcohol concentrations were 
also higher during BZ1 than during the following cruises. Marine $<\mathrm{C}_{20} n$-alcohol concentrations decreased between BZ1 and BZ2 but in lesser proportions, and terrigenous $>\mathrm{C}_{22} n$-alcohol concentrations reflected an enrichment in terrigenous components caused by the overflow of the turbidity current onto the channel levee during BZ2, and then decreased until BZ3. The higher quantities of organic material of pelagic origin in the surficial sediment at the beginning of the study period could have induced a recruitment process for the main components of surface detritus feeders (cirratulids, paraonids and spionids). A similar process could occur later for subsurface deposit feeders or mobile organisms i.e. sigalionids, ampharetids, pholoids, dorvilleids and syllids, that were shown to be also responsible for temporal changes in this study. All these processes could result in a significant increase in macrofaunal densities observed from January 2001 to December 2003. The difference between the two sites could be linked to the difference in organic matter quality (marine vs terrigenous). Indeed, $n$-alcohol concentrations indicate that sediments at ZC receive higher inputs of marine material than at ZD, and the marine $n$-alcohols degrade swiftly compared with the terrigenous ones (Treignier et al., 2006). Another factor may play a role in slowing down the response of the infaunal communities: the physical disturbance created by the turbidites near the channel. Indeed, burial beneath a few centimetres of sediments likely yields significant macrofaunal disturbance, as shown by Smith (1994) from an experimental study to evaluate the influence of mound building by infaunal organisms such as echiurans on macrobenthic community structure. He showed that community recovery in disturbed areas in the deep sea requires long periods that may last years.

Moreover, the BIOZAIRE study areas, located downslope off the Congo-Angola margin likely also receive organic matter advected from shelf and slope waters across and along the continental slope, probably transported by near bed currents as discussed by Rabouille et al. (this volume). They also suggest that episodically substantial inputs of labile organic matter can occur at site ZC. These inputs may be due to fluctuations of the Congo/Angola coastal upwelling (Voituriez and Herbland, 1982, Picaut, 1983, Soltwedel, 1997) that was shown to have a higher strength in boreal summer. Indeed, at ZC, Rabouille et al. (this volume) found seasonal variations in vertical inputs with higher values in summer than in winter. A particularly substantial input of labile organic matter could have occurred between 2002 and 2003, even if no measure in particle flux data nor in sediment data support that suggestion. Indeed, Van Gaever et al.(this volume) found exceptionally high relative abundances of the opportunistic nematode genus Microlaimus at site ZC in 2003; this genus is often found to be dominant in areas with an increased organic input. 
Similarly, some carnivorous polychaetes known to respond to organic enrichment (sigalionids, hesionids, dorvilleids) were also largely more abundant during BZ3 than during the previous cruises.

A contemporary change in vertical profiles and in densities of the macrofaunal communities was observed. These profiles (Figure 5) highlighted similar trends of distribution of the community during BZ1 and BZ2 with most of the individuals in the subsurface layers of sediment. This trend was particularly evident at ZD. A change occurred between BZ2 and BZ3, reflecting a trend of the community to move upward to the surface of the sediment at the end of the study (December 2003).

Many factors may control vertical distribution of infaunal organisms, among which environmental factors such as food and oxygen availability (Danovaro et al., 1995; Relexans et al., 1996; Soetaert et al., 1997, Vanreusel et al., 1995), quality of organic matter (marine vs terrigenous) (Dauwe et al., 1998), physical disturbance (periodic erosional/depositional events) (Thistle et al., 1985, Aller, 1997), temporal characteristics of food inputs to the seabed (constant or episodic) (Jumars et al., 1990; Lambshead et al., 1995, Witte, 2000), or biotic factors such as competition, feeding behaviour (Blake, 1994), bioturbation by large metazoans at the sediment-water interface or within the sediment column, (Jumars et al., 1990, Smith, 1992, Galéron, 2001), downward mixing of fresh organic material by small infauna (Blair et al., 1996; Levin et al., 1997).

As reported above, noticeable changes in $n$-alcohol concentrations of the surface layer of sediment were recorded during the study period suggesting higher fresh food inputs before BZ1, than during the following period. In that case, organic material could have been saved in the subsurface layers of sediment by large organisms. Indeed, echiurans and sipunculids have been shown to save up fresh labile material below the sediment-water interface to be preserved from the other large organisms living preferentially at the sediment surface (Jumars et al., 1990), making it available for smaller organisms living in the sediment column. At the two deep sites (ZC and ZD), large echiurans and sipunculids were abundant, particularly at ZD, and they could also be found in some boxcores when slicing the cores or when clearing out the box (Galéron, personal observation). Nevertheless, the trend of the macrofaunal community to move toward the surface between BZ2 and BZ3 may support the suggestion of a particularly substantial input of labile organic matter at the site ZC (Rabouille et al., this volume; Van Gaever et al., this volume). As shown by Jumars et al. (1990), turbidites can also bury organic material which becomes available to large burrowing metazoans and to smaller subsurface deposit feeders. During the BIOZAIRE study period (2000-2006), a single turbiditic event having enough energy to overflow 
the edges of the Congo channel was shown to have impacted the area in the vicinity of the channel. Nevertheless it is likely that this type of event occurs from time to time and, in case of very high energy turbiditic currents in the submarine valley, it could impact the bottom communities on a larger area.

Another reason responsible for infauna to live in subsurface layers of sediment is physical disturbance by currents (Thistle et al., 1985, Aller, 1997), but currents measured 50m a.b. by Vangriesheim et al. (this volume), do not exhibit values able to erode the surface layer of sediment. Bioturbation by moving and feeding activities of large mobile organisms at the sediment-water interface could also contribute to make the small infauna to move downward in the sediment column (Galéron et al., 2001), but data available for the megafaunal community living at both sites (bottom trawl catches and ROV videos, K. Olu and J. Galéron observations) do not exhibit high rates of megafaunal activities.

The changes observed in macrofaunal communities at the deep sites during the BIOZAIRE study period are probably driven by changes linked to a combination of factors in this complex area. The activities of the Congo system impact the benthic habitat at local scale through the episodic turbiditic currents, and also at larger scale through the river plume that extends regionally, and/or through nearbed currents as suggested by Brind'Amour et al. (this volume). Moreover the seasonal upwelling system linked to the Congo system, may also induce changes by episodic inputs of material of marine origin. By the position of the two deep sites at the bottom of the slope, these communities are also probably affected by lateral inputs transported seasonally across the slope (Rabouille et al., this volume).

\section{Conclusion}

In the Gulf of Guinea, the Congo activities influence directly or indirectly the sedimentary habitat conditions on a large area at abyssal depth, extending probably on hundreds of kilometers around the submarine system. The effects on the seafloor observed in terms of quality (marine vs terrestrial) and quantity of particulate inputs, as well as in their periodicity (seasonal vs erratic) vary according to the depth and to the distance to the channel, yielding heterogeneity of the infaunal community habitat at regional scale. In turn, the deep macrofaunal communities are spatially and temporally heterogeneous in terms of structure and distribution. Additionally, the presence of other types of habitats in the area, like cold 
seeps (Olu-Le Roy et al., 2007; Olu et al., this volume; Ondréas et al., 2005) or deep coral reefs (Le Guilloux et al., this volume), with specific associated communities, contribute to enhance the diversity of the benthic ecosystems in the complex area of the Gulf of Guinea.

\section{Acknowledgements}

The BIOZAIRE cruises were conducted in the framework of a partnership between Ifremer and the French oil company Total. The authors thank the captains, the officers and the crew of the R/V L'Atalante as well as the scientific participants. We are very grateful to A. Fifis and S. Dubut for their technical assistance in the macrofaunal sample processing and to M.C. Fabri and K. Olu who provided the maps of the study areas.

Thanks are also addressed to the reviewers who allowed to improve this manuscript. 


\section{Figure captions}

Figure 1. Position of the three study areas.

Figure 2. Position of the sites R, R3, R4, R6, R7, R9, R10 around the REGAB pockmark area.

Figure 3. Macrofauna community structure at sites ZC and ZD during the three BIOZAIRE cruises (BZ1, BZ2, BZ3), at R during BZ 2, and at the sites R3, R4, R6, R7, R9, R10 during BZ 3. Bars represent standard errors on total mean densities.

Figure 4. Temporal evolution of polychaete mean densities grouped in trophic guilds at sites ZC and ZD. Bars represent standard errors on mean densities.

Figure 5. Vertical profiles of mean macrofaunal densities from 0 to $15 \mathrm{~cm}$ depth at sites ZC and ZD during the three BIOZAIRE cruises. Bars represent standard errors on mean densities.

Figure 6. Vertical profiles of mean macrofaunal densities from 0 to 15cm depth at sites R3, R4, R6, R7, R9, R10 during BZ 3 . Bars represent standard errors on mean densities.

Figure 7. PCA performed on higher taxa density data collected at sites ZC and ZD during the three BIOZAIRE cruises, at site R during BZ2 and at the sites R3, R4, R6, R7, R9, R10 during BZ3.

Figure 8. PCA performed on polychaete family densities at sites ZC and ZD during the three BIOZAIRE cruises, at site R during BZ2 and at the sites R3, R4, R6, R7, R9, R10 during BZ3.

Figure 9. PCA performed on polychaete family densities at sites ZC and ZD for the three BIOZAIRE cruises.

Figures 10a and 10b. Organic carbon profiles at sites ZC and ZD during the three BIOZAIRE cruises.

Figure 11. Mean values of pore water (\%), nitrogen (\% of dry sediment), organic carbon (\% of dry sediment), sulfur (\% of dry sediment) and C/N ratio in the 3 first cm of sediment at sites ZC, ZD, R3, R6, R7, R9, R10 during the cruise BZ3.

Figure 12. PCA performed on mean values of pore water content, organic carbon, nitrogen and sulfur concentrations, and $\mathrm{C} / \mathrm{N}$ ratio in the 3 first cm of sediment at sites ZC and ZD during the three BIOZAIRE cruises, and at sites R3, R4, R6, R7, R9, R10 during BZ3. 
Figures 13a and 13b. $<$ C20 and $>$ C22 $n$-alcohol concentrations ( $\mu$ g/g of dry sediment) and $n$-alcohol $<$ C20/>C22 ratios in the surficial sediments recovered during the three BIOZAIRE cruises at sites ZC (14a) and ZD (14b). 


\section{References}

Bett, B.J., Malzone, M.G., Narayanaswamy, B.E., Wigham, B.D., 2001. Temporal variability in phytodetritus and megabenthic activity at the seabed in the deep Northeast Atlantic. Progress in Oceanography 50 (1-4), 349-368.

Billett, D., Bett, B., Rice, A., Thurston, M., Galéron, J., Sibuet, M., Wolff, G., 2001. Long-term changes in the megabenthos of the Porcupine Abyssal Plain (NE Atlantic). Progress in Oceanography 50 (1-4), 325-348.

Blair, N.E., Levin, L.A., DeMaster, D.J., Plaia, G., 1996. The short term fate of fresh algal carbon in continental slope sediments. Limnology and Oceanography 41 (1208-1219).

Blake, J.A., 1994. Vertical distribution of benthic infauna in continental slope sediments off Cape Lookout, North Carolina. Deep-Sea Research II 41 (4-6), 919-927.

Brind'Amour, A., Menot, L., Galéron, J., Crassous, P., this volume. Spatial organization of a sedimentary macrobenthic community located on the West African Equatorial margin.

Coynel, A., Seyler, P., Etcheber, H., Meybeck, M., Orange, D., 2005. Spatial and seasonal dynamics of total suspended sediment and organic carbon species in the Congo River. Global Biogeochemical Cycles 19, 1-17.

Dauwe, B., Herman, P.M.J., Heip, C.H.R., 1998. Communitv structure and bioturbation potential of macrofauna at four North Sea stations with contrasting food supply. Marine Ecology Progress Series 173, 67-83.

Dodélec, C., Chessel, D., 1987. Rythmes saisonniers et composantes stationnelles en milieu aquatique I.- Description d'un plan d'observation complet par projection de variable. Acta Oecologica, Oecologia Generalis 8, 403-426.

Drazen, J.C., Baldwin, R.J., Smith Jr, K.L., 1998. Sediment community response to a temporally varying food supply at an abyssal station in the NE Pacific. Deep-Sea Research 45, 893-913.

Fauchald, K., Jumars, P.A., 1979. The diet of worms: a study of polychaete feeding guilds. Oceanography and Marine Biology Annual Review $17,193-284$.

Flach, E.C., Heip, C.H.R., 1996. Vertical distribution of macrozoobenthos within the sediment on the continental slope of the Goban Spur area (NE Atlantic). Marine Ecology Progress Series 141, 55-66.

Galéron, J., Sibuet, M., Mahaut, M.L., Dinet, A., 2000. Variation in sturcture and biomass of the benthic communities at three contrasting sites in the tropical Northeast Atlantic. Marine Ecology Progress Series 197, 121-137.

Galéron, J., Sibuet, M., Vanreusel, A., Mackenzie, K., Gooday, A.J., Dinet, A., Wolff, G.A., 2001. Temporal patterns among meiofauna and macrofauna taxa related to changes in sediment geochemistry at an abyssal NE Atlantic site. Progress in Oceanography 50 (1-4), $303-324$. 
Hessler, R.R., Jumars, P.A., 1974. Abyssal community analysis from replicate box cores in the central North Pacific. Deep-Sea Research 21, 185-209.

Jumars, P.A., Mayer, L.M., Deming, J.W., Baross, J.A., Wheatcroft, R.A., 1990. Deep-sea deposit-feeding strategies suggested by environmental and feeding constraints. Philosophical Transactions of the Royal Society of London A 331, 85-101.

Khripounoff, A., Vangriesheim, A., Babonneau, N., Crassous, P., Dennielou, B., Savoye, B., 2003. Direct observation of intense turbidity current activity in the Zaire submarine valley at $4000 \mathrm{~m}$ water depth. Marine Geology 194, 151-158.

Kröncke, I., Türkay, M., 2003. Structure and function of the macrofauna communities in the deep Angola-Basin in relation to environmental factors. Marine Ecology Progress Series 260, 43-53.

Lambshead, P.J.D., Ferrero, T., Wolff, G.A., 1995. Comparison of the vertical distribution of nematodes from two contrasting abyssal sites in the Northeast Atlantic subject to different seasonal inputs of phytodetritus. Internationale Revue der gesamten Hydrobiologie 80 (2), $327-331$.

Le Guilloux, E., Bourillet, J.F., Cochonat, P., Iglésias, S.P., Sibuet, M., Olu, K., this volume. First observation of deep-sea coral reef along the Angola margin.

Legendre, P., Gallagher, P., 2001. Ecologically meaningful transformations for ordination of species data. Oecologia 129, $271-280$.

Levin, L.A., Blair, N.E., DeMaster, D.J., Plaia, G., Fornes, W., Martin, C., Thomas, C., 1997. Rapid subduction of organic matter by maldanid polychaetes on th North Carolina slope. Journal of Marine Research 55, 595-611.

Olu-Le Roy, K., Caprais, J.C., Fifis, A., Fabri, M.C., Galéron, J., Budzinsky, H. , Le Ménach, K., Khripounoff, A., Ondréas, H., Sibuet, M., 2007. Cold-seep assemblages on a giant pockmark off West Africa: spatial patterns and environmental control. Marine Ecology, 28, 115-130

Olu-Le Roy, K., Caprais, J.C., Galéron, J., Causse, R., Budzinsky, H. , Le Ménach, K., Le Roux, C., Levaché, D., Khripounoff, A., Sibuet, M., this volume. Community structure and nutritional patterns of megafaunal assemblages on an active giant pockmark in the Gulf of Guinea and local production use by mobile predators.

Ondréas, H., Olu, K., Fouquet, Y., Charlou, J., Gay, A., Dennielou, B., Donval, J., Fifis, A., Nadalig, T., Cochonat, P., Cauquil, E., Bourillet, J., Moigne, M., Sibuet, M., 2005. ROV study of a giant pockmark on the Gabon continental margin. Geo-Marine Letters 25 (5), $281-292$.

Picaut, J., 1983. Propagation of the seasonal upwelling in the eastern equatorial Atlantic. Journal of Physical Oceanography $13,18-37$.

Rabouille, C., Caprais, J.C., Lansard, B., Crassous, P., Dedieu, K., Reyss, J.L., Khripounoff, A., this volume. In situ measurements of oxygen consumption and organic matter budget in the Southeast Atlantic continental margin close to the Congo canyon.

Rex, M.A., Etter, R.J., Morris, J.S., Crouse, J., McClain, C.R., Johnson, N.A., Stuart, C.T., Deming, J.W., Thies, R., Avery, R., 2006. Global bathymetric patterns of standing stock and body size in the deep-sea benthos. Marine Ecology Progress Series 317, 1-8. 
Sibuet, M., Galéron, J., Khripounoff, A., Menot, L., Olu-Le Roy, K., Durrieu, J., Miné, J., Caprais, J.C., Crassous, P., Fabri, M.C., Vangriesheim, A., Desneulin, J., Savoye, B., Cochonat, P., Ondréas, H., Etoubleau, J., Loubrieu, B., Dinet, A., Von Cosel, R., 2002. Deep-sea ecosystems on the Equatorial African Margin: First results of a pluridisciplinary environmental programme and discovery of chemosynthesis based ecosystem. Sixth international conference on health, safety \& environment in Oil and Gas exploration and production, Kuala-Lumpur, p. 16 p.

Thioulouse, J., Chessel, D., Dolédec, S., Olivier, J.M., 1997. ADE-4: a multivariate analysis and graphical display software. Statistics and Computing 7, 75-83.

Thistle, D., Yingst, J.Y., Fauchald, K., 1985. A deep-sea benthic community exposed to strong near-bottom currents on the Scotian Rise (western Atlantic). Marine Geology 66, 91-112.

Treignier, C., Derenne, S., Saliot, A., 2006. Terrestrial and marine $n$-alcohol inputs and degradation processes relating to a sudden turbidity current in the Zaire canyon. Organic Geochemistry 37, 1170-1184.

van Bennekom, A.J., Berger, G.W., 1984. Hydrography and silica budget of the Angola basin. Netherlands Journal of sea research 17, 149-200.

van Bennekom, A.J., Berger, G.W., Helder, W., De Vries, R.T.P., 1978. Nutrient distribution in the Zaire estuary and river plume. Netherlands Journal of sea research 12 (3/4), 296-323.

Van Gaever, S., Galéron, J., Sibuet, M., Vanreusel, A., this volume. Deep-sea habitat heterogeneity influence on meiofaunal communities in the Gulf of Guinea.

Vangriesheim, A., Khripounoff, A., Crassous, P., this volume. Turbiditic events observed in situ along the Congo deep-sea channel.

Vanreusel, Cosson-Sarradin, N., Gooday, A.J., Paterson, G.L.J., Galéron, J., Sibuet, M., Vincx, M., 2001. Evidence for episodic recruitment in a small opheliid polychaete species from the abyssal NE Atlantic. Progress in Oceanography 50 (1-4), 285-301.

Vetter, E.W., Dayton, P.K., 1998. Macrofaunal communities within and adjacent to a detritus-rich submarine canyon system. Deep-Sea Research II 45, 25-54.

Voituriez, B., Herbland, A., 1982. Comparaison des systèmes productifs de l'Atlantique Tropical Est: dômes thermiques, upwellings côtiers et upwelling équatorial. Rapp P-V Réun Cons Int Explor Mer 180, pp. 114-130. 


\section{Figure 1}

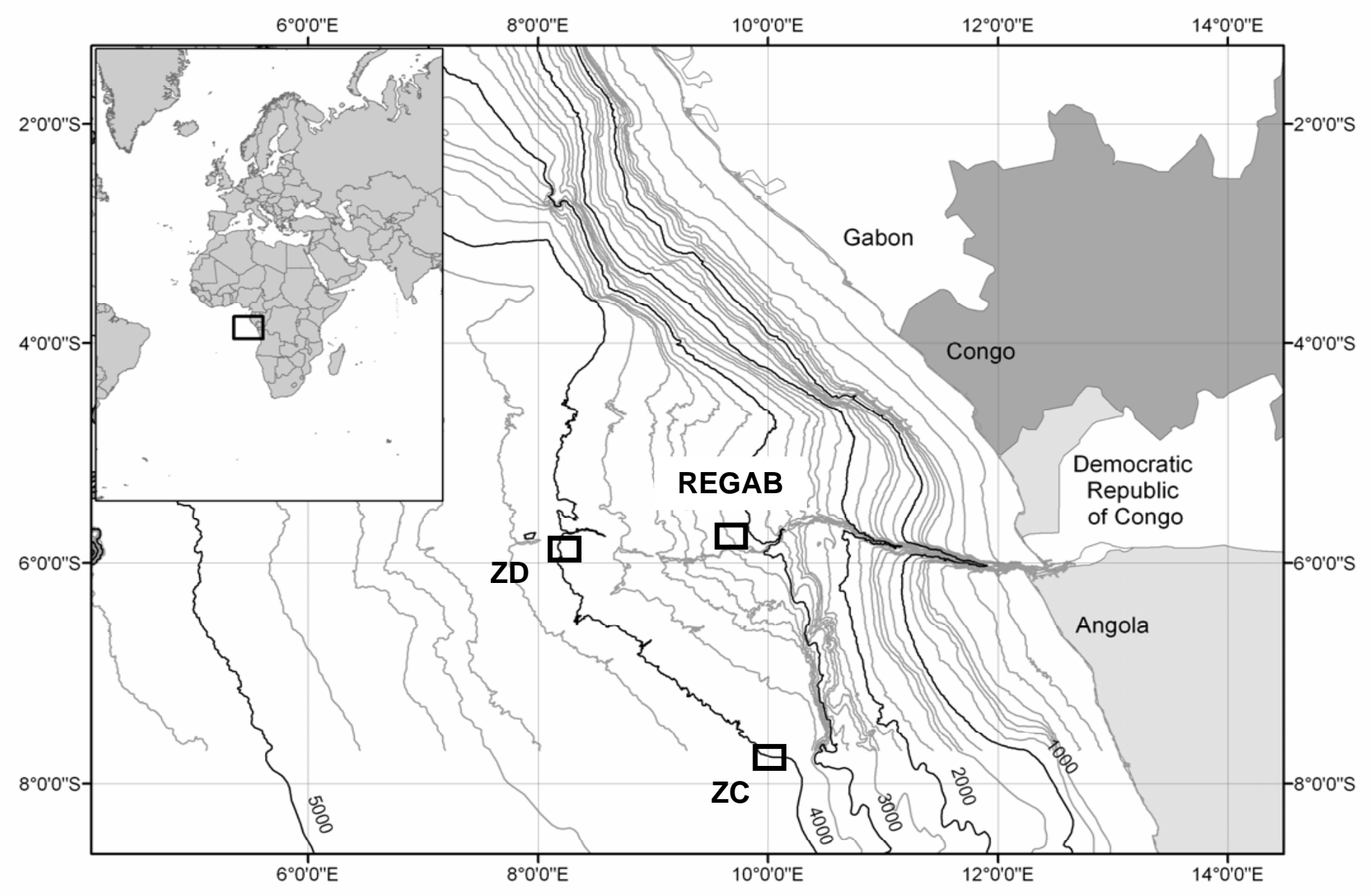


Figure 2

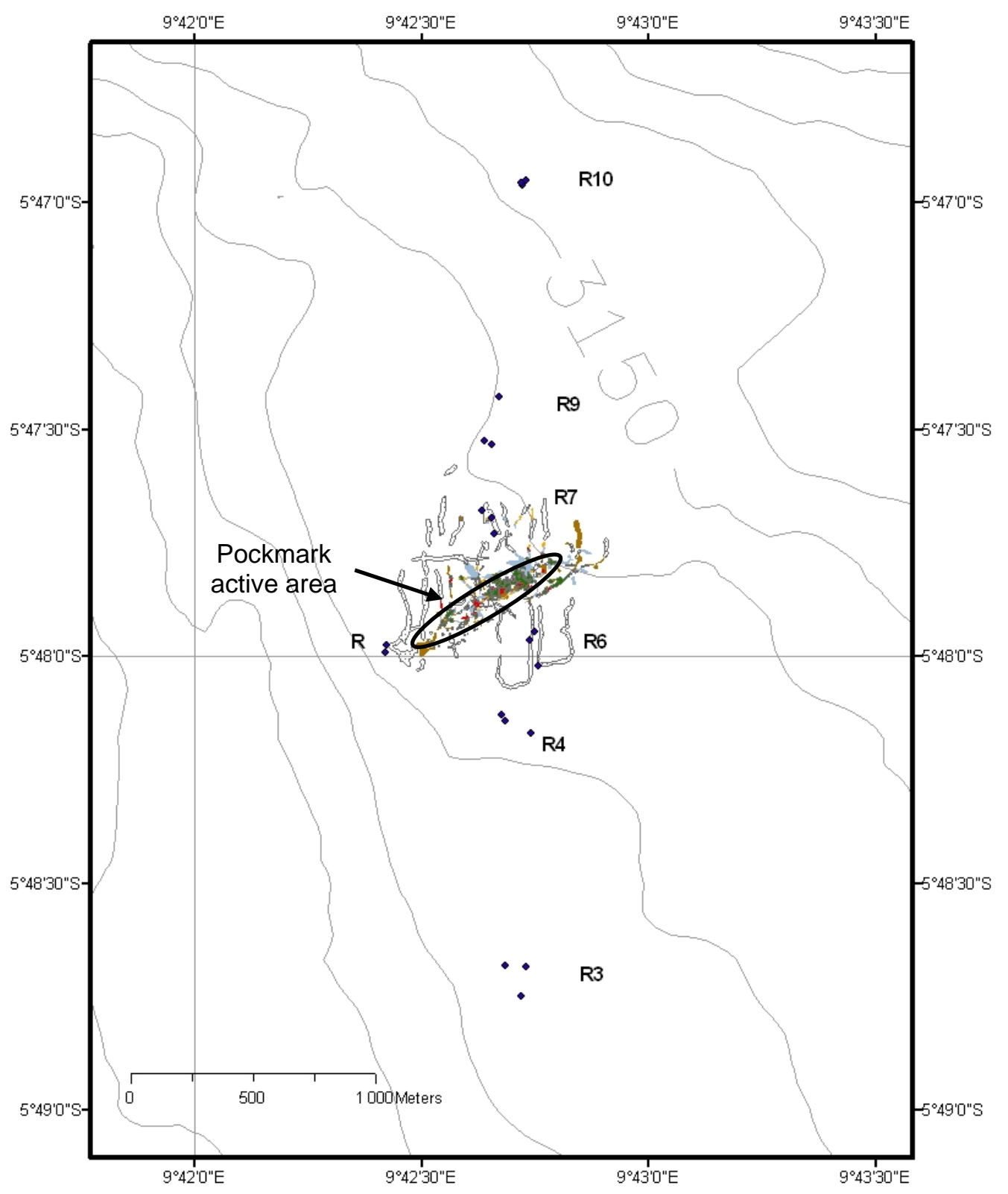


Figure 3

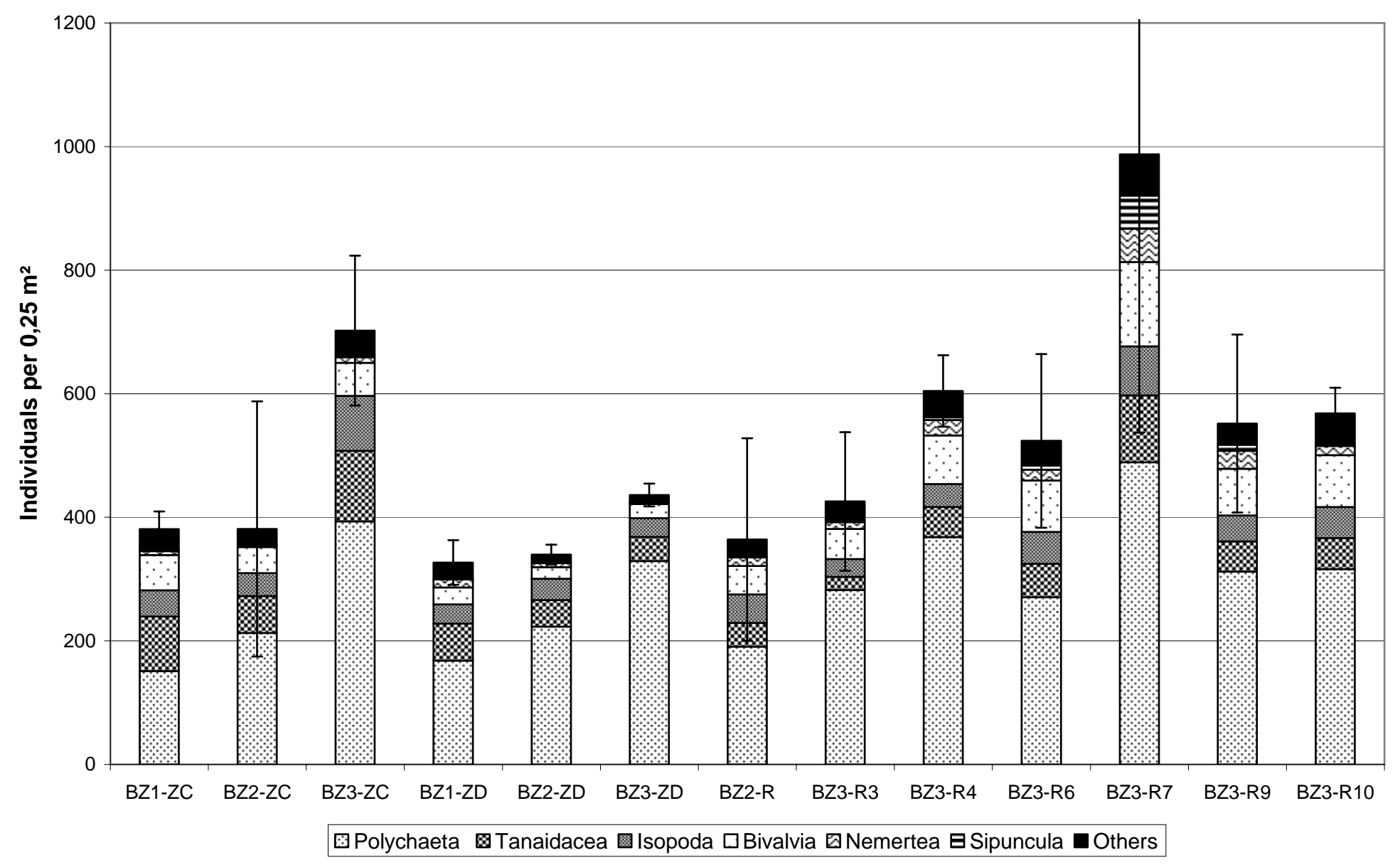


Figure 4

Site ZC

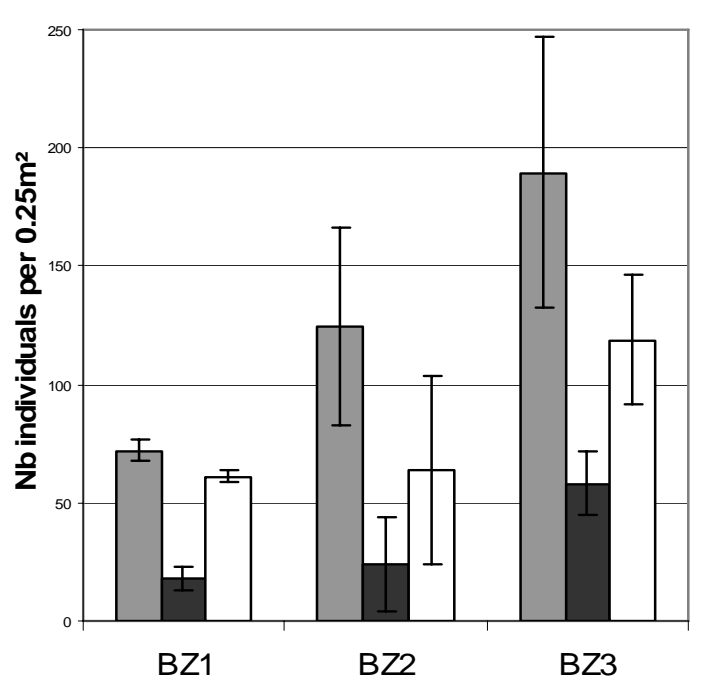

Site ZD

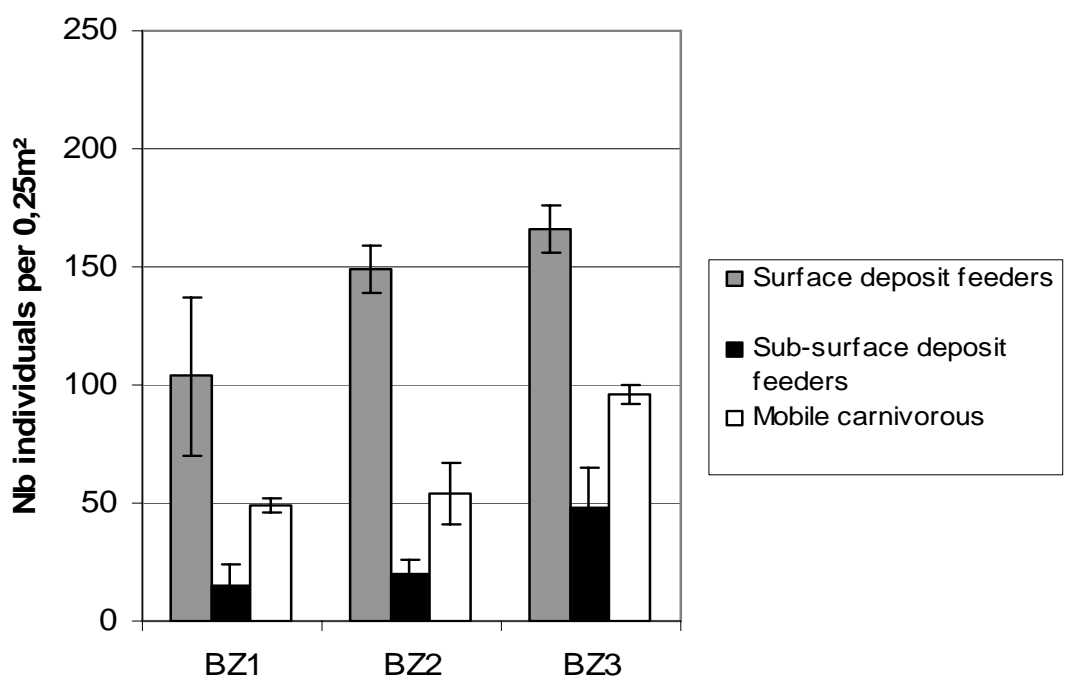


Figure 5

Site ZC

$\mathrm{Nb}$ individuals per $0.25 \mathrm{~m}^{2}$

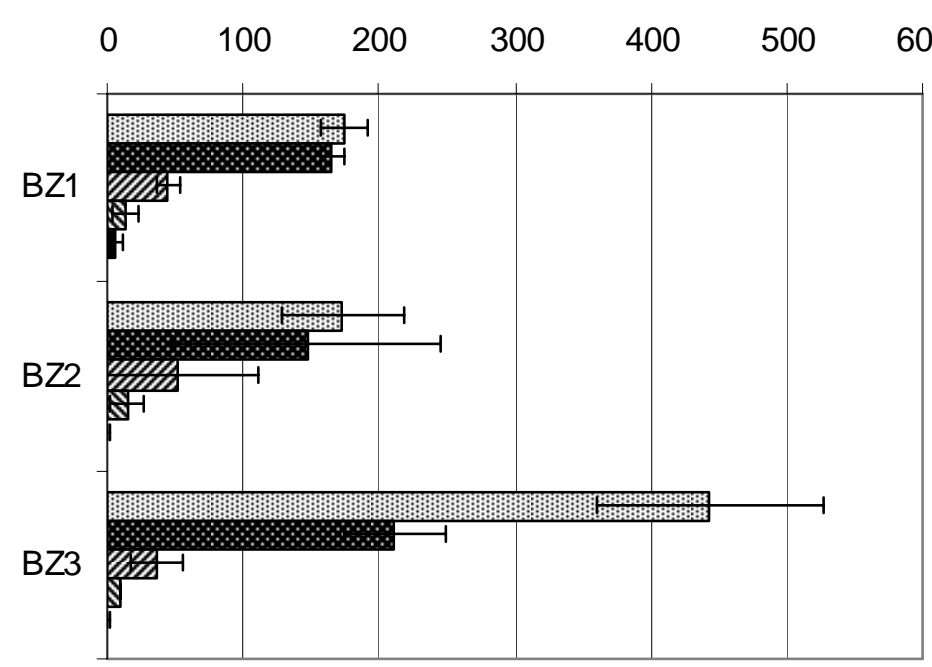

Site ZD

$\mathrm{Nb}$ individuals per $0.25 \mathrm{~m}^{2}$

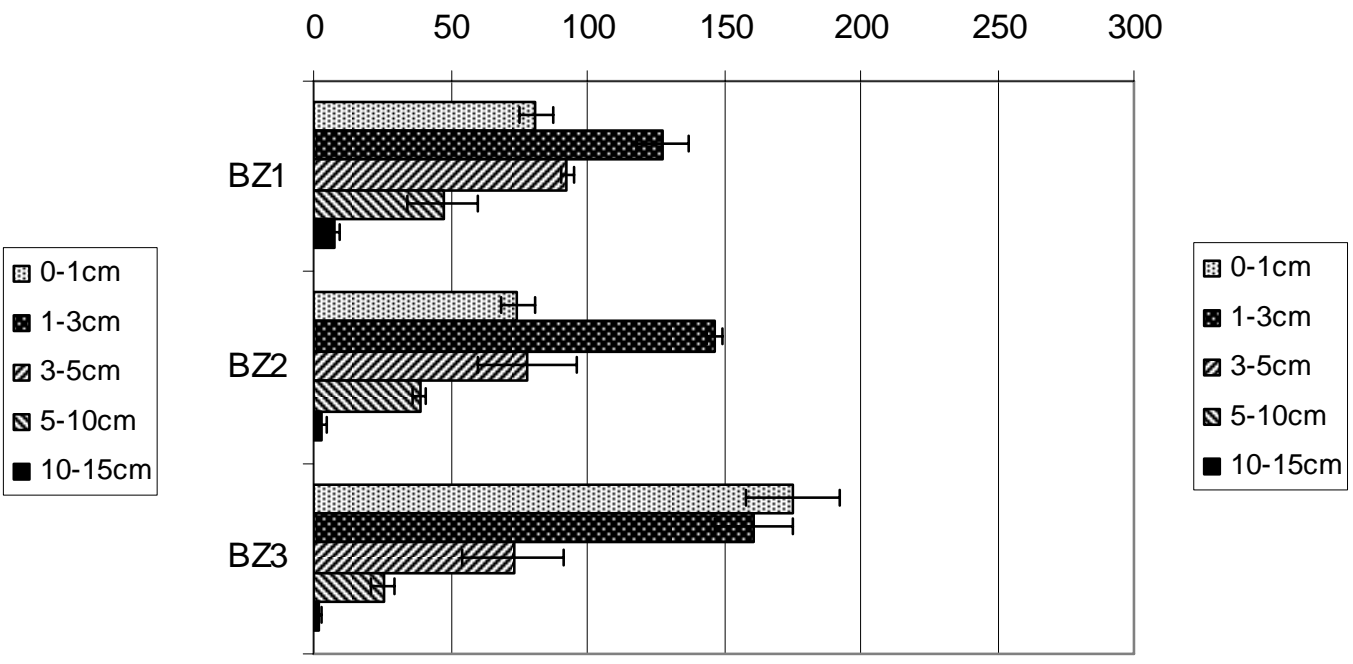




\section{Transect sites}

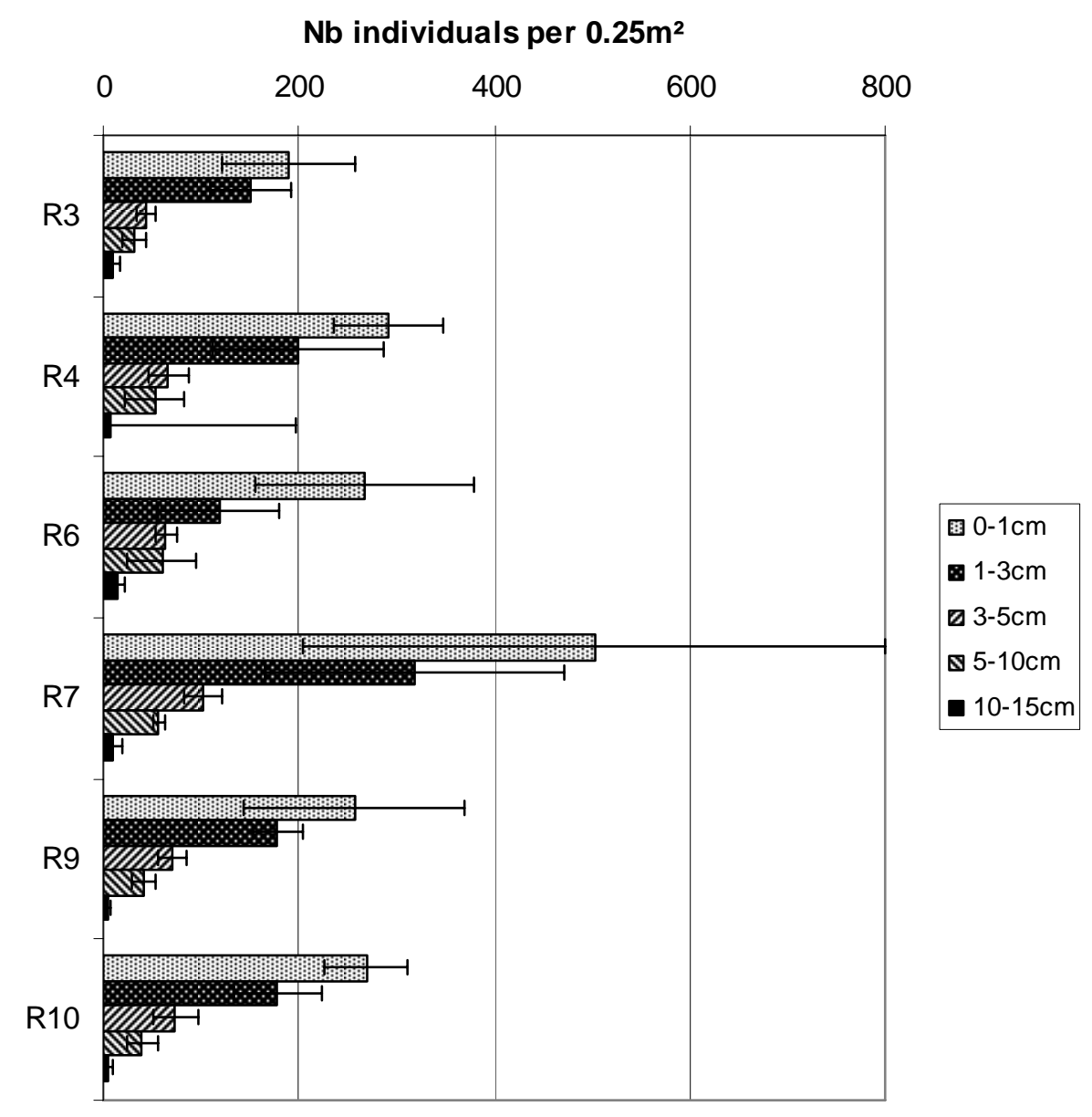

Figure 6 

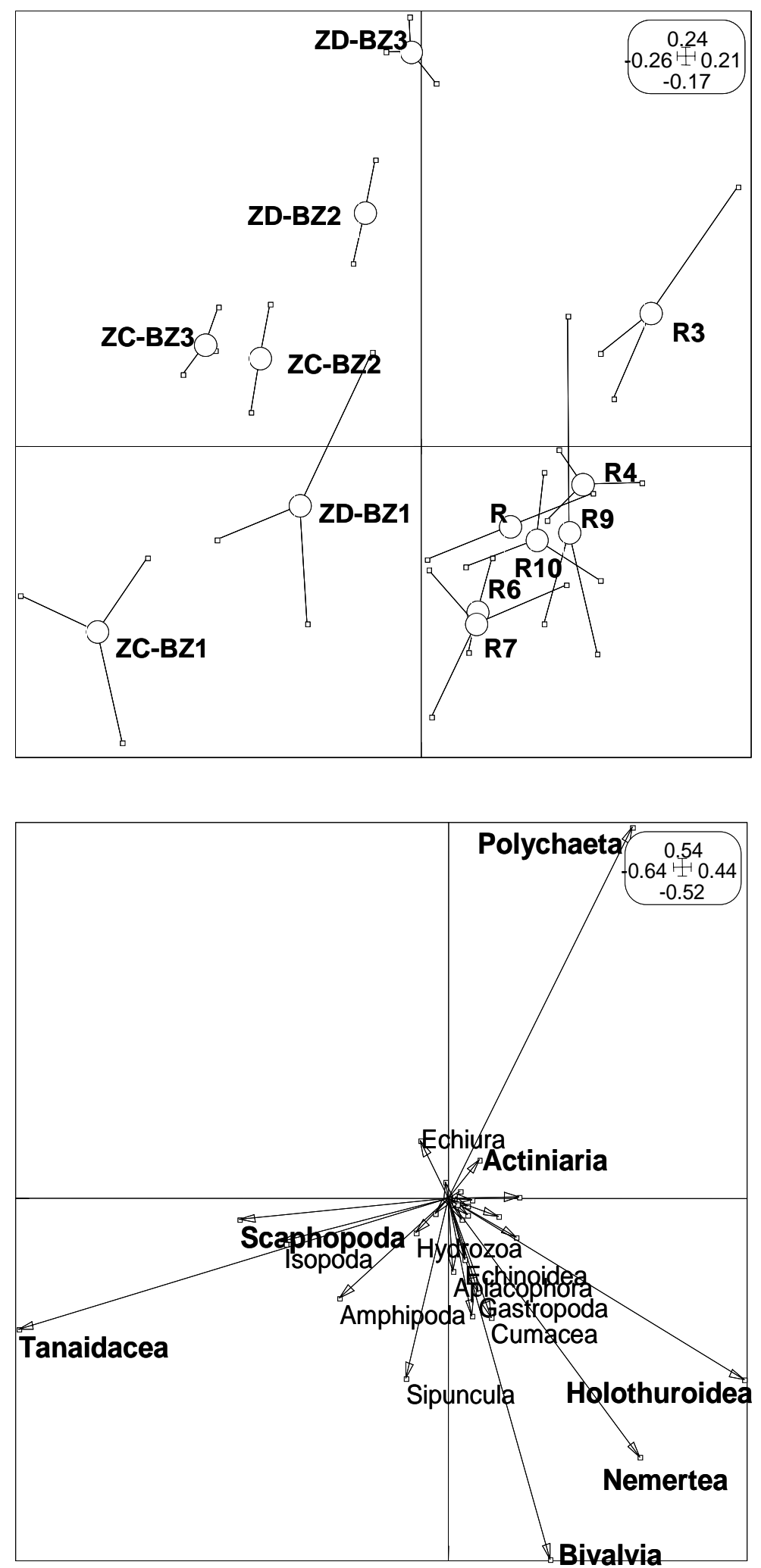

Figure 7 

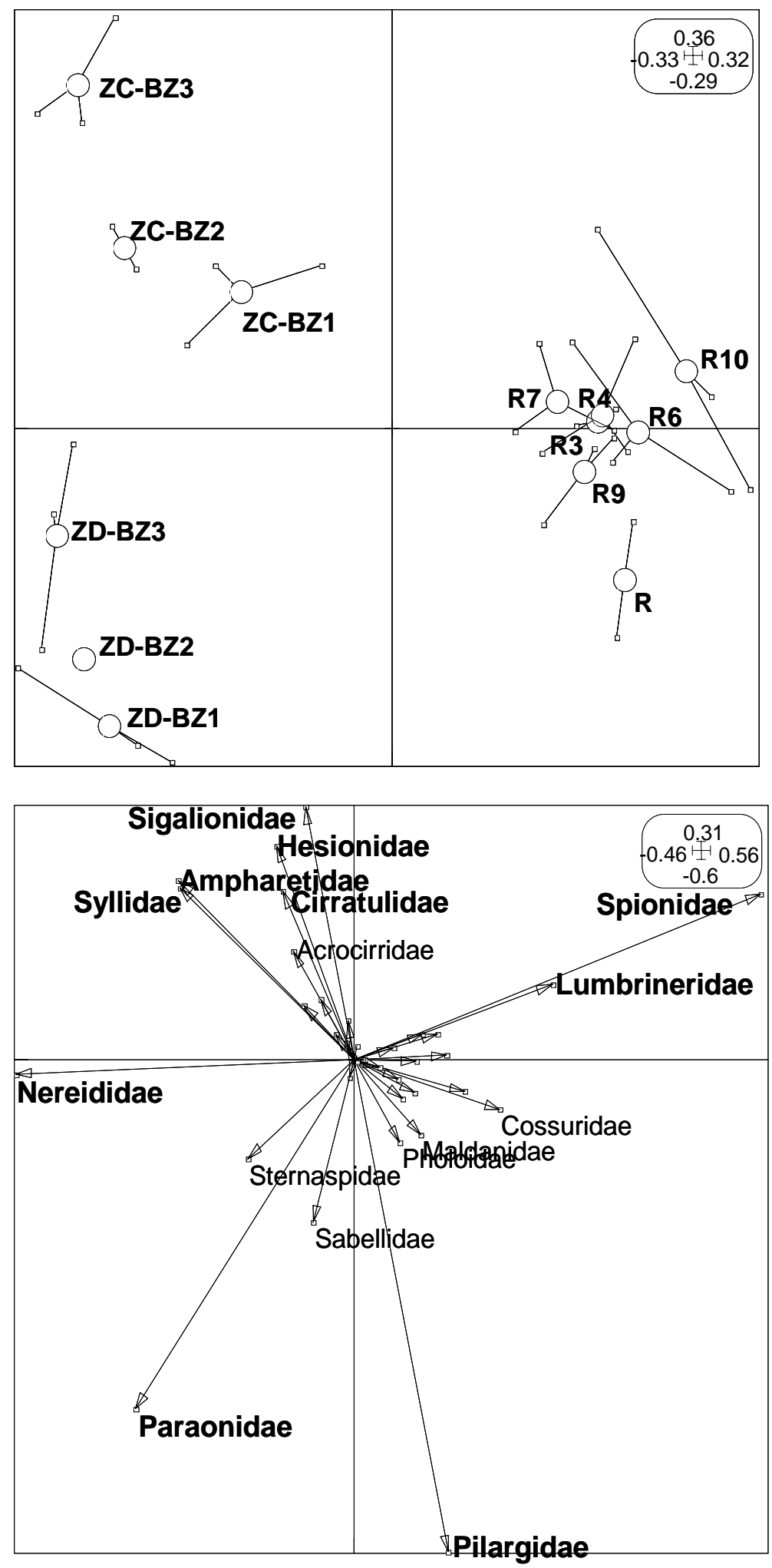

Figure 8 

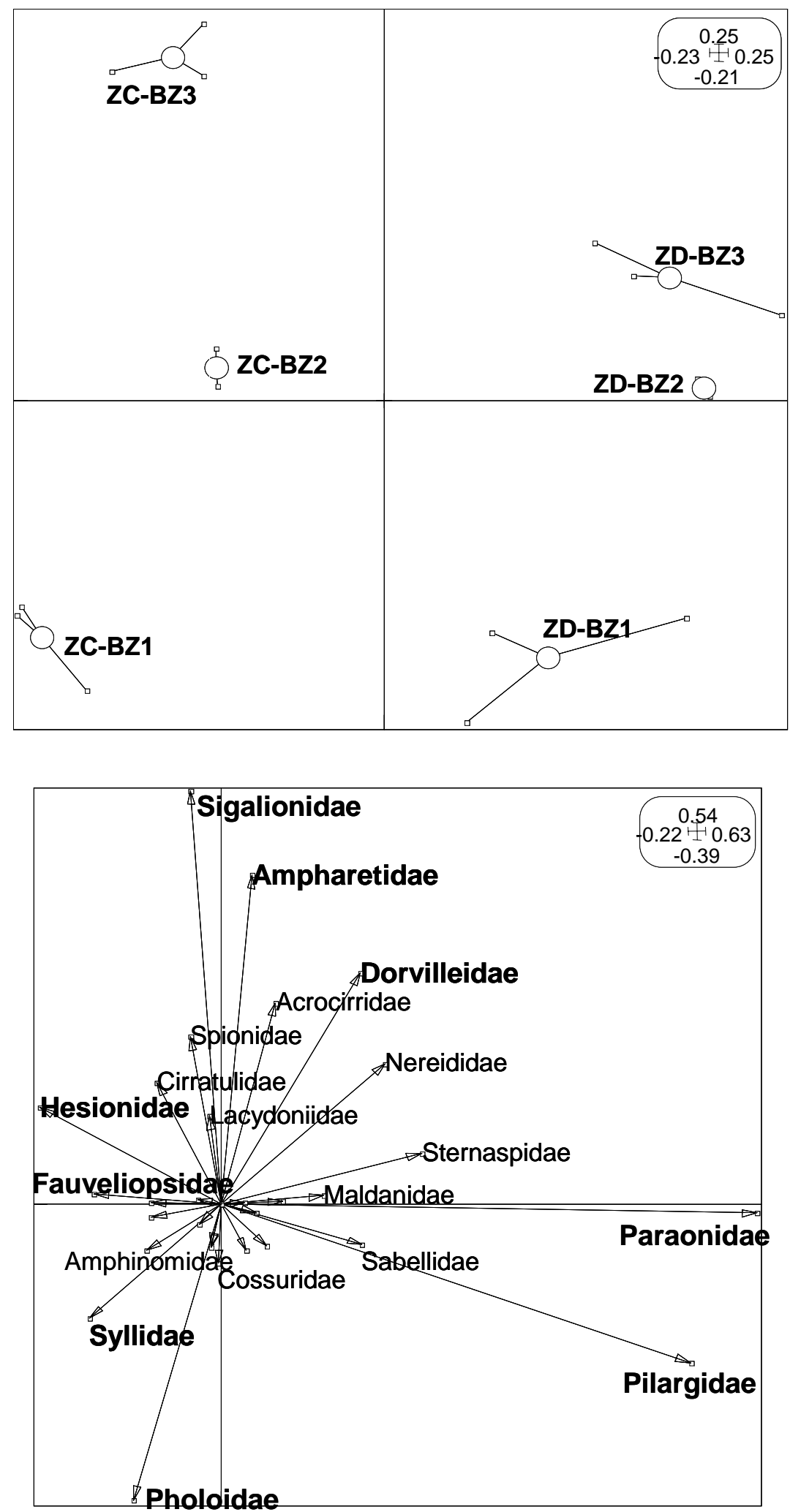

\section{Figure 9}




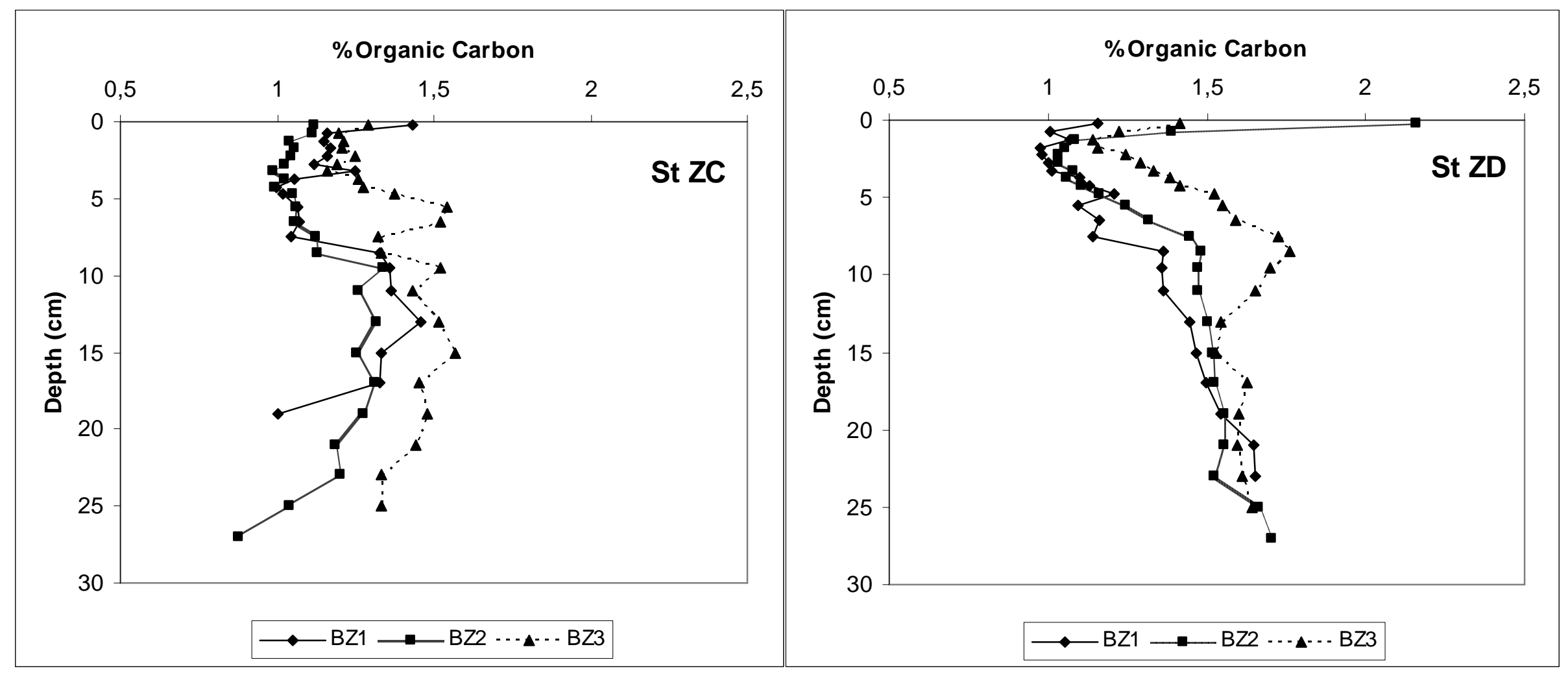

Figures 10a and 10b 

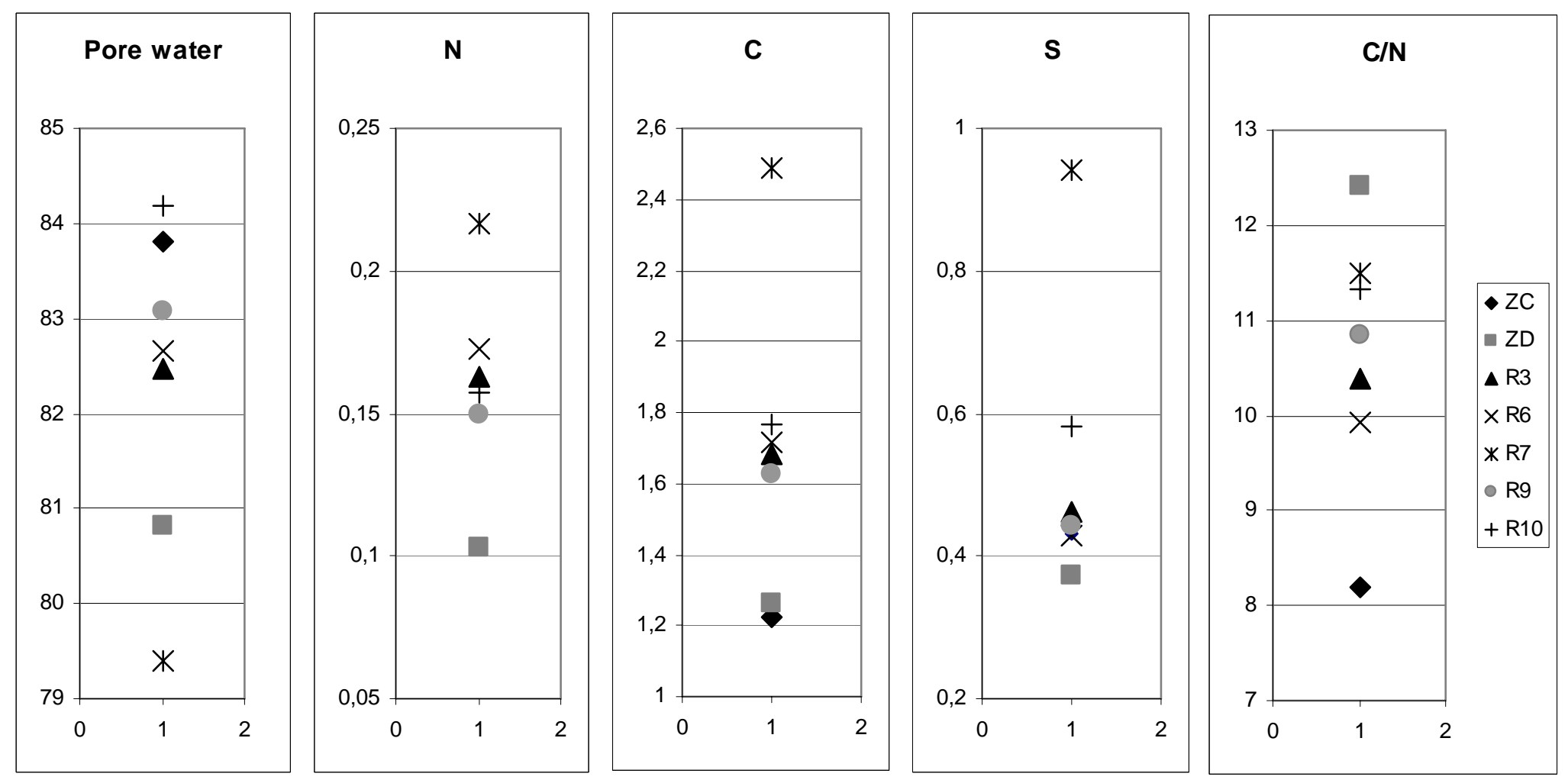

Figure11 
Figure 12
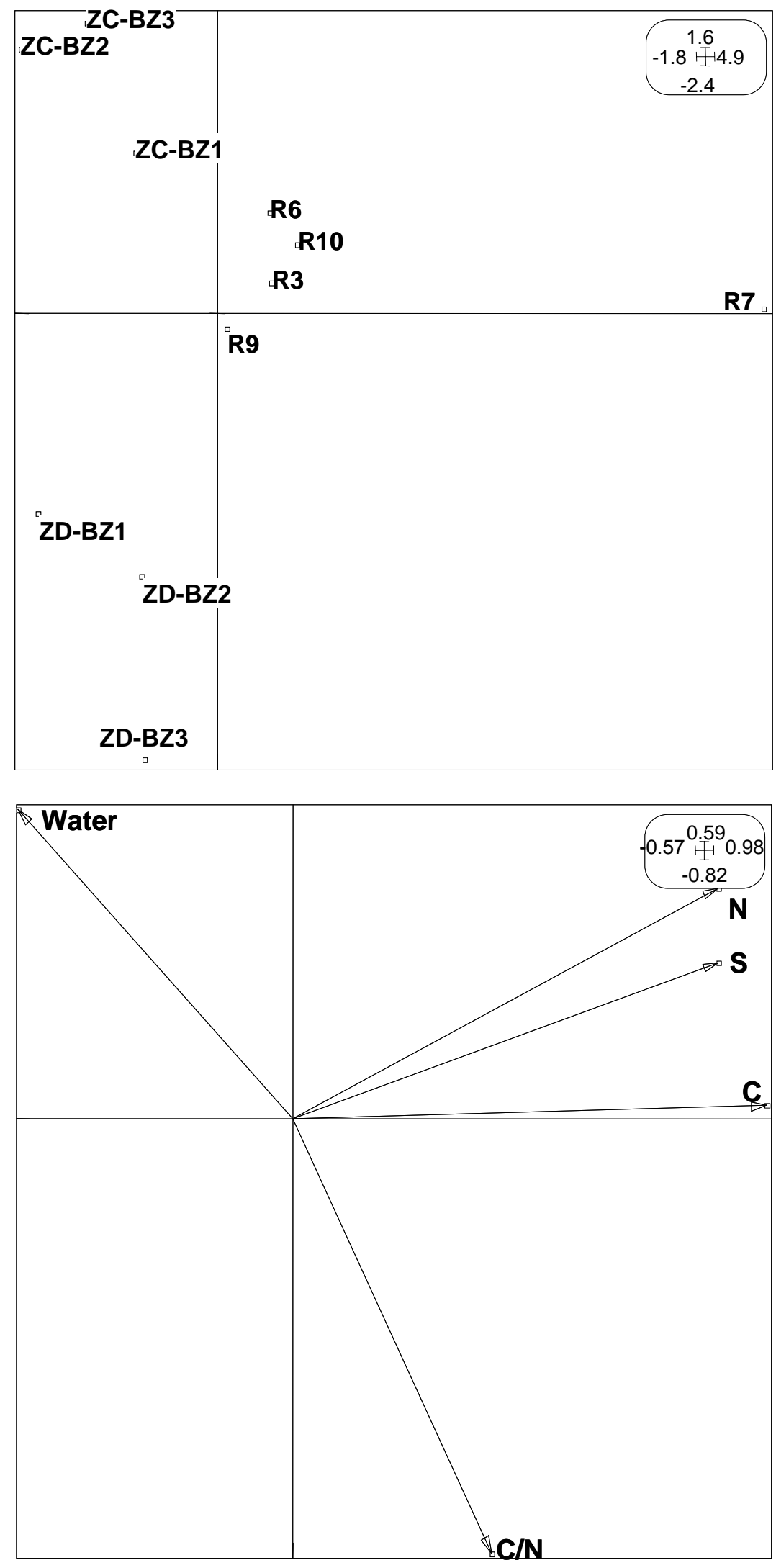
Figures 13a and 13b
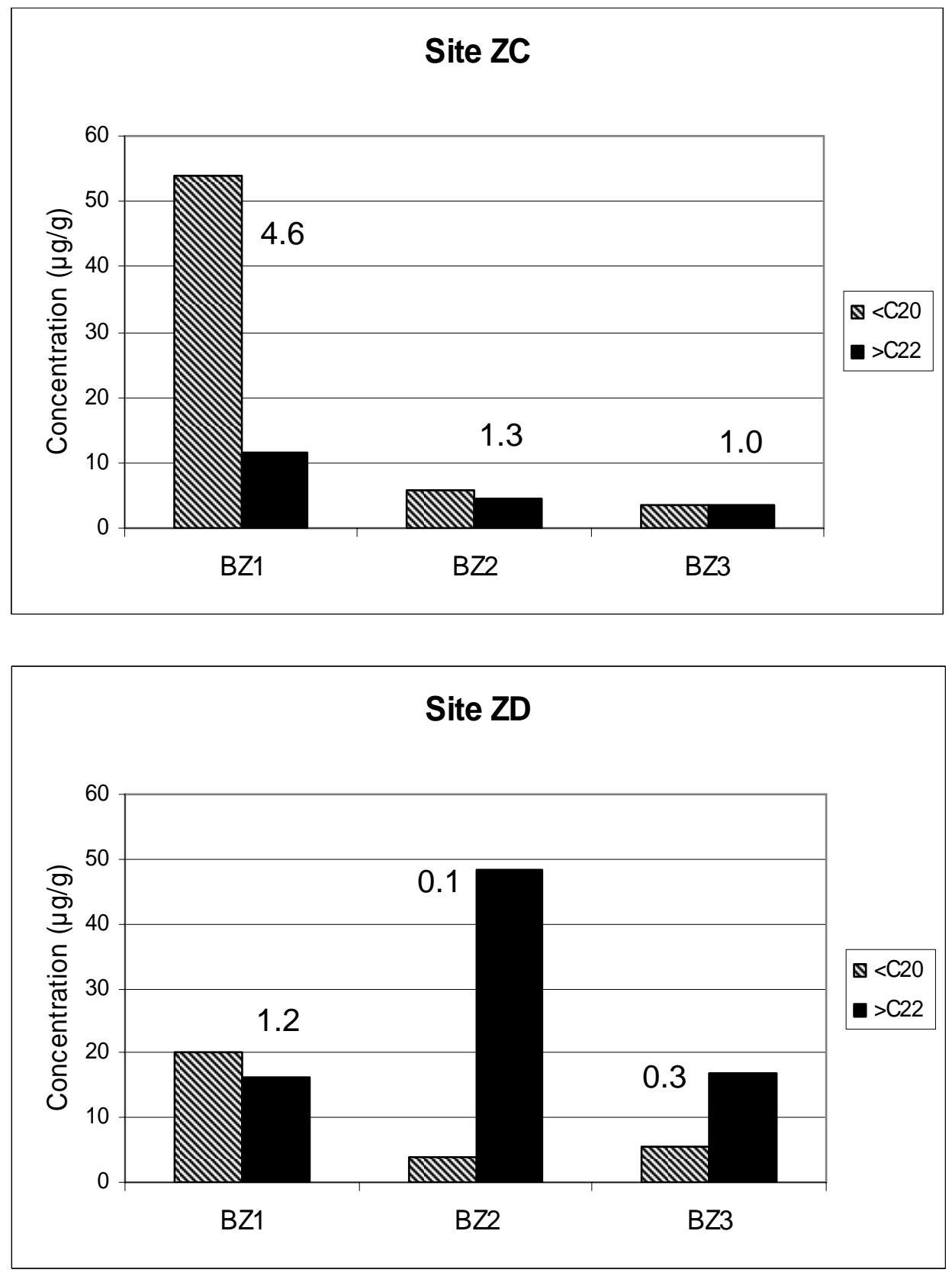
Table 1: Numbers of replicate samples per site and per cruise

\begin{tabular}{|c|c|c|c|}
\hline Site & $\begin{array}{c}\text { BIOZAIRE 1 } \\
\text { Jan-2001 }\end{array}$ & $\begin{array}{c}\text { BIOZAIRE 2 } \\
\text { Dec-2001 }\end{array}$ & $\begin{array}{c}\text { BIOZAIRE 3 } \\
\text { Dec-2003 }\end{array}$ \\
\hline $\begin{array}{c}\text { ZC } \\
\text { (150km South Congo canyon) }\end{array}$ & 3 & 2 & 3 \\
\hline $\begin{array}{c}\text { ZD } \\
(15 \mathrm{~km} \text { South Congo canyon) }\end{array}$ & 3 & 2 & 3 \\
\hline $\begin{array}{c}\mathbf{R} \\
(250 \mathrm{~m} \text { from active area) }\end{array}$ & & 2 & 3 \\
\hline $\begin{array}{c}\mathbf{R 3} \\
(1000 \mathrm{~m} \text { from active area) }\end{array}$ & & & 3 \\
\hline $\begin{array}{c}\mathbf{R 4} \\
\text { (500m from active area) }\end{array}$ & & & 3 \\
\hline $\begin{array}{c}\mathbf{R 6} \\
(250 \mathrm{~m} \text { from active area) }\end{array}$ & & & 3 \\
\hline $\begin{array}{c}\mathbf{R 7} \\
(250 \mathrm{~m} \text { from active area) }\end{array}$ & & & 3 \\
\hline $\begin{array}{c}\mathbf{R 9} \\
(500 \mathrm{~m} \text { from active area) }\end{array}$ & & & 3 \\
\hline $\begin{array}{c}\mathbf{R 1 0} \\
(1000 \mathrm{~m} \text { from active area) }\end{array}$ & & & \\
\hline
\end{tabular}


Table 2: Macrofaunal mean densities (D: Nb of individuals per $0.25 \mathrm{~m}^{2}$ ) and standard deviations (SD (Nb of samples)) at sites ZC and ZD during the three BIOZAIRE cruises, at site R during BZ2 and at sites R3, R4, R6, R7, R9, R10 during BZ3

\begin{tabular}{|c|c|c|c|c|c|c|c|c|c|c|c|c|c|c|c|c|c|c|c|c|c|c|c|c|c|c|}
\hline & \multicolumn{6}{|c|}{ ZC } & \multicolumn{6}{|c|}{ ZD } & \multirow{2}{*}{\multicolumn{2}{|c|}{$\begin{array}{c}\mathbf{R} \\
\text { BIOZAIRE } 2 \\
\text { Dec-2001 }\end{array}$}} & \multicolumn{2}{|c|}{ R3 } & \multicolumn{2}{|c|}{ R4 } & \multicolumn{2}{|c|}{ R6 } & \multicolumn{2}{|c|}{ R7 } & \multicolumn{2}{|c|}{ R9 } & \multicolumn{2}{|c|}{ R10 } \\
\hline & \multicolumn{2}{|c|}{$\begin{array}{c}\text { BIOZAIRE } 1 \\
\text { Jan-2001 }\end{array}$} & \multicolumn{2}{|c|}{$\begin{array}{c}\text { BIOZAIRE } 2 \\
\text { Dec-2001 }\end{array}$} & \multicolumn{2}{|c|}{$\begin{array}{c}\text { BIOZAIRE } 3 \\
\text { Dec-2003 }\end{array}$} & \multicolumn{2}{|c|}{$\begin{array}{c}\text { BIOZAIRE } 1 \\
\text { Jan-2001 }\end{array}$} & \multicolumn{2}{|c|}{$\begin{array}{c}\text { BIOZAIRE } 2 \\
\text { Dec-2001 }\end{array}$} & \multicolumn{2}{|c|}{ BIOZAIRE 3} & & & \multicolumn{2}{|c|}{$\begin{array}{c}\text { BIOZAIRE } 3 \\
\text { Dec-2003 }\end{array}$} & \multicolumn{2}{|c|}{$\begin{array}{c}\text { BIOZAIRE } 3 \\
\text { Dec-2003 }\end{array}$} & \multicolumn{2}{|c|}{$\begin{array}{c}\text { BIOZAIRE } 3 \\
\text { Dec-2003 }\end{array}$} & \multicolumn{2}{|c|}{$\begin{array}{c}\text { BIOZAIRE } 3 \\
\text { Dec-2003 }\end{array}$} & \multicolumn{2}{|c|}{$\begin{array}{c}\text { BIOZAIRE } 3 \\
\text { Dec-2003 }\end{array}$} & \multicolumn{2}{|c|}{$\begin{array}{c}\text { BIOZAIRE } 3 \\
\text { Dec-2003 }\end{array}$} \\
\hline & & $\begin{array}{l}\text { SD } \\
(3) \\
\end{array}$ & & $\begin{array}{l}\text { SD } \\
(2) \\
\end{array}$ & $\mathrm{D}$ & $\begin{array}{l}\text { SD } \\
(3) \\
\end{array}$ & & $\begin{array}{l}\mathrm{SD} \\
(3) \\
\end{array}$ & & $\begin{array}{l}\text { SD } \\
(2) \\
\end{array}$ & $\mathrm{D}$ & $\begin{array}{l}\text { SD } \\
(3)\end{array}$ & & $\begin{array}{l}\text { SD } \\
(2) \\
\end{array}$ & & $\begin{array}{l}\text { SD } \\
(3) \\
\end{array}$ & & $\begin{array}{l}\mathrm{SD} \\
(3) \\
\end{array}$ & & $\begin{array}{l}\text { SD } \\
(3) \\
\end{array}$ & & $\begin{array}{l}\text { SD } \\
(3) \\
\end{array}$ & & $\begin{array}{l}\text { SD } \\
(3) \\
\end{array}$ & & $\begin{array}{l}\text { SD } \\
(3) \\
\end{array}$ \\
\hline Porifera & 0 & 0 & 0 & 0 & 0 & 0 & 0 & 0 & 0 & 0 & 0,3 & 0,6 & 0 & 0 & 0 & 0 & 0,7 & 1,2 & 0 & 0 & 1,3 & 2,3 & 0,7 & 1,2 & 0 & 0 \\
\hline Hydrozoa & 0,3 & 0,6 & 0 & 0 & 1 & 1 & 1 & 1 & 0 & 0 & 0 & 0 & 0,5 & 0,7 & 0 & 0 & 1,3 & 2,3 & 0 & 0 & 1 & 1 & 0 & 0 & 0 & 0 \\
\hline Actiniaria & 0,3 & 0,6 & 1,5 & 2,1 & 0 & 0 & 0,7 & 1,2 & 0 & 0 & 0 & 0 & 0 & 0 & 4 & 3 & 0 & 0 & 0 & 0 & 0 & 0 & 0 & 0 & 0 & 0 \\
\hline Anthozoa & 0 & 0 & 0 & 0 & 0 & 0 & 0 & 0 & 0 & 0 & 0 & 0 & 0 & 0 & 0 & 0 & 0 & 0 & 0 & 0 & 0 & 0 & 0 & 0 & 2 & 2 \\
\hline Nemertea & 6 & 1 & 1 & 0 & 9 & 9,5 & 13 & 6,9 & 6,5 & 0,7 & 1,7 & 1,2 & 14 & 5,7 & 11 & 4,4 & 24,7 & 12,5 & 17,7 & 9 & 53,7 & 42 & 29 & 17,1 & 14,7 & 10 \\
\hline Priapulida & 0 & 0 & 0 & 0 & 0 & 0 & 0 & 0 & 0,5 & 0,7 & 0 & 0 & 0 & 0 & 0 & 0 & 0 & 0 & 0 & 0 & 0 & 0 & 0 & 0 & 0 & 0 \\
\hline Polychaeta (total) & 151 & 5,3 & 212,5 & 101,1 & 393,3 & 88,9 & 167,7 & 38,8 & 223 & 17 & 329 & 12,8 & 190,5 & 65,8 & 282,3 & 62,3 & 367,7 & 33,6 & 270,3 & 79,4 & 489 & 180,6 & 312 & 44,5 & 316 & 40 \\
\hline Acrocirridae & 0,7 & 1,2 & 3,5 & 4,9 & 9,3 & 5,1 & 1 & 1,7 & 1 & 1,4 & 9 & 6,6 & 0 & 0 & 2,7 & 2,1 & 3 & 1,7 & 1,7 & 1,5 & 4 & 6,1 & 1 & 1,7 & 1,3 & 0,6 \\
\hline Ampharetidae & 0 & 0 & 8 & 9,9 & 23,3 & 3,1 & 0,7 & 0,6 & 4,5 & 2,1 & 4,7 & 0,6 & 0 & 0 & 1,3 & 1,5 & 1,3 & 1,5 & 0,3 & 0,6 & 1 & 1,7 & 0,3 & 0,6 & 0 & 0 \\
\hline Amphinomidae & 4 & 2,6 & 2 & 2,8 & 5,7 & 1,5 & 3 & 2,6 & 1 & 0 & 1 & 1 & 4,5 & 0,7 & 2 & 0 & 4,7 & 4 & 6,7 & 3,8 & 7,3 & 4,9 & 4,7 & 2,1 & 3 & 0 \\
\hline Aphroditidae & 0 & 0 & 0 & 0 & 0 & 0 & 0 & 0 & 0 & 0 & 0 & 0 & 0 & 0 & 0 & 0 & 0 & 0 & 0 & 0 & 0 & 0 & 0 & 0 & 0 & 0 \\
\hline Capitellidae & 1 & 1 & 4 & 1,4 & 1,7 & 2,9 & 1,3 & 1,2 & 2 & 1,4 & 0,3 & 0,6 & 3,5 & 0,7 & 1,7 & 1,2 & 2,3 & 2,3 & 2 & 2 & 6 & 4 & 2,3 & 1,2 & 3,3 & 2,1 \\
\hline Chrysopetalidae & 0 & 0 & 0 & 0 & 0 & 0 & 0 & 0 & 0 & 0 & 0 & 0 & 0 & 0 & 2 & 1 & 1,3 & 2,3 & 0,3 & 0,6 & 0,3 & 0,6 & 2,3 & 1,5 & 0,7 & 1,2 \\
\hline Cirratulidae & 35,3 & 3,2 & 55,5 & 9,2 & 89 & 39 & 25 & 4,6 & 37 & 9,9 & 44 & 12,3 & 32,5 & 3,5 & 42,3 & 9 & 60,3 & 11,6 & 44,3 & 19,9 & 57,7 & 26,4 & 49,3 & 10,6 & 40,3 & 8 \\
\hline Cossuridae & 0,7 & 0,6 & 0 & 0 & 0 & 0 & 0,3 & 0,6 & 1 & 1,4 & 0 & 0 & 3,5 & 0,7 & 2,7 & 1,2 & 3 & 1 & 3,3 & 1,2 & 12,7 & 12,9 & 4,3 & 2,5 & 1,7 & 0,6 \\
\hline Dorvilleidae & 0,3 & 0,6 & 3 & 1,4 & 9,3 & 2,5 & 0,7 & 1,2 & 8,5 & 6,4 & 9 & 6,9 & 3,5 & 2,1 & 2,7 & 2,9 & 4,7 & 1,5 & 3,3 & 3,5 & 5,7 & 7,2 & 6,7 & 4 & 4 & 0 \\
\hline Fauveliopsidae & 2,3 & 1,5 & 1 & 1,4 & 2,7 & 2,5 & 0 & 0 & 0 & 0 & 0,7 & 1,2 & 0 & 0 & 1 & 1 & 3,3 & 1,5 & 2,3 & 2,1 & 2 & 1,7 & 1,7 & 0,6 & 0,7 & 0,6 \\
\hline Flabelligeridae & 0 & 0 & 0 & 0 & 0,7 & 1,2 & 1,3 & 0,6 & 0 & 0 & 0 & 0 & 1 & 1,4 & 0,7 & 1,2 & 0,7 & 0,6 & 1,3 & 0,6 & 1,3 & 0,6 & 0,7 & 0,6 & 1 & 0 \\
\hline Goniadidae & 0 & 0 & 0 & 0 & 0 & 0 & 0 & 0 & 0 & 0 & 0 & 0 & 0 & 0 & 0 & 0 & 0 & 0 & 0 & 0 & 0 & 0 & 0,3 & 0,6 & 0,3 & 0,6 \\
\hline Glyceridae & 1,7 & 0,6 & 2 & 0 & 3 & 1,7 & 1,7 & 1,2 & 4,5 & 2,1 & 1,7 & 0,6 & 6,5 & 2,1 & 4,7 & 1,5 & 5,3 & 4 & 3,3 & 2,1 & 6,3 & 4,5 & 4,7 & 0,6 & 4 & 1 \\
\hline Hesionidae & 5,3 & 6,1 & 8 & 8,5 & 12,3 & 3,2 & 0,7 & 0,6 & 1 & 0 & 1,3 & 2,3 & 1 & 1,4 & 1,7 & 2,9 & 0,7 & 1,2 & 1,7 & 1,2 & 2,3 & 2,1 & 2,3 & 2,5 & 2,3 & 2,5 \\
\hline Lacydoniidae & 0 & 0 & 0 & 0 & 2 & 1,7 & 0 & 0 & 0 & 0 & 0,7 & 1,2 & 0 & 0 & 0 & 0 & 0 & 0 & 0 & 0 & 0 & 0 & 0 & 0 & 0 & 0 \\
\hline Lumbrineridae & 5 & 2,6 & 6,5 & 6,4 & 4,7 & 2,1 & 1,7 & 1,5 & 1,5 & 0,7 & 3,7 & 1,2 & 10 & 2,8 & 17,7 & 4 & 18 & 4,6 & 10,3 & 3,2 & 22,7 & 6,7 & 18,3 & 8,7 & 19,7 & 3,8 \\
\hline Maldanidae & 0 & 0 & 0 & 0 & 0,3 & 0,6 & 0,7 & 0,6 & 0,5 & 0,7 & 1,7 & 1,2 & 0,5 & 0,7 & 1,7 & 1,2 & 0,7 & 1,2 & 9,3 & 2,5 & 6,7 & 7,6 & 2,3 & 2,5 & 0,3 & 0,6 \\
\hline Nephtyidae & 2,3 & 1,2 & 2 & 0 & 2,3 & 1,5 & 2,7 & 1,2 & 2 & 0 & 4 & 2,6 & 3,5 & 0,7 & 8 & 3,6 & 14,3 & 3,8 & 7,7 & 5 & 15,7 & 0,6 & 7 & 2 & 10 & 1,7 \\
\hline Nereididae & 4,3 & 2,9 & 7 & 2,8 & 31,7 & 21,7 & 10 & 5,2 & 17,5 & 0,7 & 18 & 1 & 0,5 & 0,7 & 0 & 0 & 0,7 & 1,2 & 0,7 & 0,6 & 7,3 & 7,6 & 1,3 & 1,2 & 0 & 0 \\
\hline
\end{tabular}




\begin{tabular}{|c|c|c|c|c|c|c|c|c|c|c|c|c|c|c|c|c|c|c|c|c|c|c|c|c|c|c|}
\hline Opheliidae & 10 & 1,7 & 5,5 & 3,5 & 11,7 & 0,6 & 6,7 & 4 & 7,5 & 9,2 & 20,7 & 8,6 & 9,5 & 2,1 & 20,7 & 8,5 & 21,7 & 6,7 & 18,3 & 11,5 & 43 & 29,5 & 18,7 & 3,8 & 23,7 & 8 \\
\hline Orbiniidae & 0 & 0 & 0 & 0 & 0 & 0 & 0 & 0 & 0,5 & 0,7 & 0 & 0 & 0 & 0 & 0 & 0 & 0 & 0 & 0 & 0 & 0 & 0 & 0,3 & 0,6 & 0 & 0 \\
\hline Pholoidae & 7 & 1 & 2 & 2,8 & 0 & 0 & 5 & 1,7 & 1 & 1,4 & 0 & 0 & 3 & 2,8 & 3,3 & 5,8 & 3,3 & 4,9 & 3,3 & 2,9 & 5 & 4,4 & 6,3 & 7,8 & 6 & 5,2 \\
\hline Paraonidae & 20 & 8,2 & 44 & 19,8 & 53,3 & 8 & 64 & 30,8 & 87,5 & 7,8 & 95 & 21 & 25 & 5,7 & 45,7 & 6,7 & 46,7 & 11,8 & 37,3 & 21,4 & 61,7 & 11,6 & 47 & 8,2 & 38 & 7,8 \\
\hline Phyllodocidae & 1,3 & 0,6 & 0 & 0 & 4,7 & 3,5 & 1,7 & 1,2 & 0 & 0 & 0,7 & 1,2 & 0 & 0 & 1,7 & 1,2 & 1 & 1,7 & 1,7 & 2,1 & 0,3 & 0,6 & 0 & 0 & 0 & 0 \\
\hline Pilargidae & 0,7 & 0,6 & 1,5 & 2,1 & 0 & 0 & 14,3 & 3,1 & 13 & 4,2 & 20 & 1,7 & 18 & 4,2 & 10 & 2,6 & 18,3 & 9,3 & 13,7 & 2,3 & 15,3 & 5,1 & 18 & 2,6 & 12,3 & 11,2 \\
\hline Polynoidae & 0 & 0 & 0 & 0 & 0 & 0 & 0 & 0 & 0 & 0 & 0 & 0 & 0 & 0 & 0 & 0 & 0 & 0 & 0,3 & 0,6 & 0 & 0 & 0,7 & 1,2 & 7,7 & 13,3 \\
\hline Sabellidae & 3 & 2,6 & 0,5 & 0,7 & 4,7 & 5,5 & 4,3 & 3,2 & 7 & 5,7 & 6,7 & 3,5 & 11 & 11,3 & 6,7 & 2,1 & 8,3 & 5,9 & 0,7 & 1,2 & 2,7 & 1,5 & 4,3 & 1,5 & 1 & 1,7 \\
\hline Scalibregmatidae & 0 & 0 & 0 & 0 & 0 & 0 & 0 & 0 & 0 & 0 & 0 & 0 & 0 & 0 & 0 & 0 & 0 & 0 & 0 & 0 & 0 & 0 & 0,3 & 0,6 & 0 & 0 \\
\hline Siboglinidae & 0 & 0 & 0 & 0 & 0 & 0 & 0 & 0 & 0 & 0 & 0 & 0 & 0 & 0 & 0,3 & 0,6 & 0 & 0 & 0,7 & 1,2 & 0 & 0 & 0 & 0 & 0 & 0 \\
\hline Sigalionidae & 0,3 & 0,6 & 0,5 & 0,7 & 33,3 & 14,2 & 0 & 0 & 0,5 & 0,7 & 9 & 4 & 1,5 & 0,7 & 2 & 2,6 & 4 & 2,6 & 4,7 & 4,2 & 4,3 & 0,6 & 2,7 & 1,5 & 2 & 2,6 \\
\hline Sphaerodoridae & 3,3 & 4,2 & 1 & 1,4 & 6,3 & 1,5 & 3 & 2 & 1 & 1,4 & 3 & 2,6 & 4 & 4,2 & 5,7 & 5,7 & 10 & 3,6 & 6,3 & 3,2 & 7 & 4,6 & 7 & 3,6 & 7 & 1,7 \\
\hline Spionidae & 13 & 2,6 & 24,5 & 12 & 42 & 6,9 & 8,7 & 8,1 & 17,5 & 2,1 & 20,3 & 0,6 & 46,5 & 31,8 & 80 & 13,9 & 105,7 & 7,1 & 73,7 & 26,7 & 122,7 & 53,1 & 77,3 & 35,5 & 104 & 9,6 \\
\hline Sternaspidae & 0 & 0 & 1 & 0 & 0,7 & 1,2 & 1,3 & 1,5 & 2 & 1,4 & 7,7 & 3,2 & 0 & 0 & 0 & 0 & 1 & 1 & 0 & 0 & 0 & 0 & 0 & 0 & 0,3 & 0,6 \\
\hline Syllidae & 28,7 & 2,9 & 29,5 & 13,4 & 12 & 10,6 & 7,7 & 2,3 & 3,5 & 0,7 & 27,3 & 8,1 & 1,5 & 2,1 & 9,3 & 5,5 & 9,3 & 3,8 & 3,3 & 3,2 & 36,7 & 54,9 & 8 & 3 & 8,3 & 5,7 \\
\hline Terebellidae & 0,3 & 0,6 & 0 & 0 & 0 & 0 & 0 & 0 & 0 & 0 & 0 & 0 & 0 & 0 & 0,3 & 0,6 & 0 & 0 & 0 & 0 & 0,3 & 0,6 & 0 & 0 & 0 & 0 \\
\hline Trichobranchidae & 0,3 & 0,6 & 0 & 0 & 0 & 0 & 0,3 & 0,6 & 0 & 0 & 0 & 0 & 0 & 0 & 0 & 0 & 0 & 0 & 1,3 & 1,5 & 1,7 & 1,5 & 0,3 & 0,6 & 0,7 & 0,6 \\
\hline Polychaeta non id. & 0 & 0 & 0 & 0 & 26,7 & 7,6 & 0 & 0 & 0 & 0 & 19 & 8,9 & 0 & 0 & 4 & 4 & 14 & 9,5 & 6,3 & 3,2 & 29,3 & 35,3 & 11,3 & 10,2 & 12,3 & 7,5 \\
\hline Aplacophora & 5,7 & 2,1 & 3,5 & 2,1 & 6 & 2,6 & 5,7 & 2,1 & 3 & 1,4 & 4 & 1,7 & 5,5 & 2,1 & 5 & 2,6 & 4,7 & 2,1 & 8,3 & 1,2 & 10 & 4,4 & 7 & 6,2 & 12 & 7 \\
\hline Pogonophora & 0,3 & 0,6 & 0,5 & 0,7 & 0 & 0 & 2 & 2,6 & 0 & 0 & 0 & 0 & 0 & 0 & 0 & 0 & 0 & 0 & 4,3 & 4 & 0,3 & 0,6 & 2,3 & 1,5 & 6,7 & 11,5 \\
\hline Gastropoda & 1,3 & 1,5 & 5,5 & 7,8 & 4,3 & 4,2 & 0,3 & 0,6 & 1 & 1,4 & 0,7 & 1,2 & 3 & 4,2 & 2 & 1,7 & 2,7 & 3,1 & 3,3 & 1,5 & 17 & 17,3 & 3,3 & 3,1 & 3,7 & 3,5 \\
\hline Bivalvia & 57,3 & 23,5 & 42,5 & 26,2 & 53,7 & 16,6 & 27,3 & 2,5 & 18,5 & 9,2 & 22,7 & 3,2 & 46 & 25,5 & 48,7 & 25,1 & 79 & 13,1 & 83,3 & 38,6 & 136,7 & 25,6 & 75,7 & 32 & 84 & 13 \\
\hline Scaphopoda & 9,3 & 4 & 0,5 & 0,7 & 10 & 2,6 & 3 & 2,6 & 0,5 & 0,7 & 1,3 & 0,6 & 1 & 1,4 & 2,3 & 1,5 & 0,7 & 1,2 & 2 & 2,6 & 2,3 & 1,5 & 0 & 0 & 1 & 1 \\
\hline Echiura & 0 & 0 & 0 & 0 & 2 & 2 & 0,3 & 0,6 & 1 & 1,4 & 1 & 1,7 & 0 & 0 & 0 & 0 & 0,3 & 0,6 & 0,7 & 1,2 & 0 & 0 & 0 & 0 & 0,3 & 0,6 \\
\hline Sipuncula & 3,7 & 1,5 & 3 & 1,4 & 2,7 & 0,6 & 0,7 & 0,6 & 0,5 & 0,7 & 1 & 1,7 & 0 & 0 & 0 & 0 & 4,3 & 3,1 & 6,7 & 9,9 & 53,3 & 85,5 & 10 & 8,7 & 2,7 & 1,2 \\
\hline Decapoda & 0 & 0 & 0 & 0 & 0 & 0 & 0 & 0 & 0 & 0 & 0 & 0 & 0 & 0 & 0 & 0 & 0 & 0 & 0 & 0 & 0 & 0 & 0 & 0 & 0,3 & 0,6 \\
\hline Cumacea & 1,3 & 0,6 & 0,5 & 0,7 & 3 & 2,6 & 0,7 & 0,6 & 0,5 & 0,7 & 1 & 1 & 3 & 1,4 & 1 & 1 & 3 & 1,7 & 4,3 & 1,5 & 7,3 & 1,5 & 3 & 2,6 & 4,7 & 2,1 \\
\hline Leptostraca & 0 & 0 & 0 & 0 & 0 & 0 & 0 & 0 & 0 & 0 & 0 & 0 & 0 & 0 & 0,3 & 0,6 & 0,7 & 1,2 & 0,3 & 0,6 & 0 & 0 & 0,7 & 1,2 & 0,3 & 0,6 \\
\hline Tanaidacea & 88,3 & 22,1 & 60 & 26,9 & 114 & 22,6 & 60,3 & 4,2 & 43 & 2,8 & 39,3 & 9,7 & 38,5 & 20,5 & 21,3 & 9 & 49 & 14,5 & 54,7 & 13,8 & 108 & 52 & 49 & 5,2 & 50,3 & 9,1 \\
\hline Isopoda & 42,3 & 7,4 & 37 & 25,5 & 89 & 16,1 & 31 & 16,4 & 34,5 & 12 & 30,3 & 5,9 & 46 & 42,4 & 28,7 & 13 & 37 & 6 & 51 & 5,3 & 79,7 & 51,7 & 41,7 & 27,8 & 50,3 & 13,3 \\
\hline Amphipoda & 12,7 & 6,4 & 13 & 11,3 & 13,7 & 7,2 & 9,7 & 7,1 & 6 & 2,8 & 3,7 & 1,5 & 7,5 & 2,1 & 8 & 7,5 & 11,7 & 1,5 & 9 & 3,6 & 17,3 & 4,2 & 8,3 & 3,1 & 7,7 & 2,1 \\
\hline Bryozoa & 0 & 0 & 0 & 0 & 0 & 0 & 0 & 0 & 0 & 0 & 0 & 0 & 0 & 0 & 1,7 & 2,9 & 9 & 15,6 & 0 & 0 & 0 & 0 & 0 & 0 & 0,3 & 0,6 \\
\hline Asteroidea & 0 & 0 & 0 & 0 & 0 & 0 & 0 & 0 & 0 & 0 & 0 & 0 & 0 & 0 & 0,3 & 0,6 & 0 & 0 & 0 & 0 & 0 & 0 & 0 & 0 & 0 & 0 \\
\hline Ophiuroidea & 0 & 0 & 0 & 0 & 0 & 0 & 0 & 0 & 0 & 0 & 0 & 0 & 1 & 0 & 0,3 & 0,6 & 1,7 & 2,9 & 0,3 & 0,6 & 0,3 & 0,6 & 0,3 & 0,6 & 0,7 & 0,6 \\
\hline Echinoidea & 0,3 & 0,6 & 0 & 0 & 0,3 & 0,6 & 1 & 0 & 0,5 & 0,7 & 0 & 0 & 0,5 & 0,7 & 0,3 & 0,6 & 1 & 1 & 0,7 & 0,6 & 1,3 & 1,5 & 0,7 & 1,2 & 1,3 & 1,5 \\
\hline
\end{tabular}




\begin{tabular}{|c|c|c|c|c|c|c|c|c|c|c|c|c|c|c|c|c|c|c|c|c|c|c|c|c|c|c|}
\hline Holothuroidea & 0 & & 0 & 0 & 0 & 0 & 2,3 & 0,6 & 0,5 & 0,7 & 0 & 0 & 7 & 1,4 & 8,3 & 6,1 & 5,3 & & 6,7 & 2,1 & 8,7 & 3,2 & 7,7 & 5,5 & 9,3 & 3,5 \\
\hline Tunicata & 0,3 & 0,6 & 0 & 0 & 0 & 0 & 0 & 0 & 0 & 0 & 0 & 0 & 0 & 0 & 0 & 0 & 0 & 0 & 0 & 0 & 0 & 0 & 0,3 & 0,6 & 0 & 0 \\
\hline Fotal & 380,7 & 28,7 & 381 & 206 & 702 & 121,4 & 326,7 & 36,2 & 339,5 & 16,3 & 436 & 18,4 & 364 & 164 & 425,7 & 112,3 & 604,3 & 57,7 & 523,7 & 140,6 & 987,3 & 450,3 & 551,7 & 143,8 & 568,3 & 41,5 \\
\hline
\end{tabular}


Table 3: Comparison of macrofaunal densities between the cruises BZ1 and BZ3 and between the sites ZC and ZD (ANOVA). *** $\mathrm{p}<0.01$, ** $\mathrm{p}<0.05$, * $\mathrm{p}<0.1$, NS, non significant

\begin{tabular}{|c|c|c|c|c|c|c|c|c|}
\hline & Total macrofauna & Polychaeta & Tanaidacea & Isopoda & Bivalvia & $\begin{array}{c}\text { Polychaeta } \\
\text { Surface deposit } \\
\text { feeders }\end{array}$ & $\begin{array}{c}\text { Polychaeta } \\
\text { Sub-surface } \\
\text { deposit feeders }\end{array}$ & $\begin{array}{c}\text { Polychaeta } \\
\text { Mobile } \\
\text { carnivorous }\end{array}$ \\
\hline ZC/ZD & $\star \star$ & NS & $\star \star \star$ & $\star \star$ & $\star \star$ & NS & NS & $\star$ \\
\hline BZ1/BZ3 & $\star \star \star$ & $\star \star \star$ & NS & NS & NS & $\star \star \star$ & NS & NS \\
\hline Cruise:Site & $\star$ & NS & $\star$ & NS & NS & NS & NS \\
\hline
\end{tabular}


Table 4: Concentration of individual compounds, of marine $<\mathrm{C}_{20}$ and terrigenous $>C_{22} n$ alcohols, and of total $n$-alcohols ( $\mu \mathrm{g} / \mathrm{g}$ of dry sediment) in the surficial sediments recovered at sites ZC and ZD during the BIOZAIRE cruises.

\begin{tabular}{|c|c|c|c|c|c|c|}
\hline & \multicolumn{3}{|c|}{ Site ZC } & \multicolumn{3}{|c|}{ Site ZD } \\
\hline Compound & BIOZAIRE 1 & BIOZAIRE 2 & BIOZAIRE 3 & BIOZAIRE 1 & BIOZAIRE 2 & BIOZAIRE 3 \\
\hline 14 & 1,84 & 0,28 & 0,09 & 0,41 & 0,16 & 0,09 \\
\hline 15 & 1,5 & 0,04 & 0,04 & 0,29 & 0,1 & 0,05 \\
\hline 16 & 28,15 & 2,65 & 1,61 & 9,06 & 1,31 & 2,32 \\
\hline 17 & 1,19 & 0,33 & 0,05 & 0,48 & 0,15 & 0,07 \\
\hline 18 & 19,76 & 1,69 & 1,25 & 9,25 & 1,07 & 2,3 \\
\hline 19 & 0,23 & 0,33 & 0,22 & 0,12 & 0,47 & 0,33 \\
\hline 20 & 1,22 & 0,34 & 0,29 & 0,49 & 0,72 & 0,33 \\
\hline 21 & 0 & 0 & 0 & 0 & 0 & 0 \\
\hline 22 & 0 & 0,41 & 0,43 & 0 & 3,43 & 1,33 \\
\hline 23 & 0,2 & 0,11 & 0,11 & 0,28 & 0,86 & 0,35 \\
\hline 24 & 0,88 & 0,5 & 0,46 & 1,37 & 6,19 & 2,16 \\
\hline 25 & 0,17 & 0,11 & 0,11 & 0,3 & 1,09 & 0,42 \\
\hline 26 & 1,19 & 0,56 & 0,46 & 1,92 & 7,87 & 2,73 \\
\hline 27 & 0,32 & 0,1 & 0,09 & 0,34 & 1,24 & 0,46 \\
\hline 28 & 3,87 & 0,8 & 0,46 & 4,98 & 8,64 & 2,82 \\
\hline 29 & 0,47 & 0,15 & 0,18 & 0,31 & 1,69 & 0,64 \\
\hline 30 & 2,84 & 0,65 & 0,56 & 3,79 & 7,41 & 2,51 \\
\hline 31 & 0,32 & 0,15 & 0,22 & 0,28 & 1,24 & 0,44 \\
\hline 32 & 0,78 & 0,42 & 0,32 & 1,73 & 5,26 & 1,8 \\
\hline 33 & 0,41 & 0,09 & 0,06 & 0,36 & 0,65 & 0,25 \\
\hline 34 & 0,22 & 0,4 & 0,09 & 0,6 & 2,03 & 0,71 \\
\hline 35 & 0 & 0 & 0,03 & 0 & 0,6 & 0,23 \\
\hline$<\mathrm{C} 20$ & 53,89 & 5,67 & 3,55 & 20,1 & 3,97 & 5,49 \\
\hline$>\mathrm{C} 22$ & 11,66 & 4,45 & 3,57 & 16,29 & 48,21 & 16,83 \\
\hline Total & 65,55 & 10,12 & 7,12 & 36,38 & 52,18 & 22,32 \\
\hline
\end{tabular}

